\title{
LA ENFITEUSIS COMO FORMA DE COLONIZACIÓN EN EL MAYORAZGO CASTELLANO DEL MARQUESADO DE ESPINARDO. LOS SEÑORÍOS DE ALBATANA Y ONTUR (1751-1893)
}

\author{
Juan Romero González
}

\section{RESUMEN}

Es un hecho conocido que en Andalucía, Castilla o La Mancha, los señores territoriales mantenían durante el Antiguo Régimen el pleno dominio sobre la tierra, que era cedida a diferentes cultivadores en régimen de arrendamiento a corto plazo. En estos casos, la abolición de derechos señoriales significó únicamente la pérdida de sus derechos exclusivos, privativos y prohibitivos, pero consolidaron como propiedad privada sus respectivos patrimonios. Pero también puede encontrarse en el ámbito castellano casos, como el de los señoríos de Ontur, Albatana y Agramón, pertenecientes al mayorazgo del marquesado de Espinardo, donde la evolución siguió líneas paralelas a las que experimentaron los territorios de señorío en la antigua Corona de Aragón e incluso en Galicia. La introducción de la relación enfitéutica, como única forma de colonizar y rentabilizar los señoríos mencionados, posibilitó una dinámica evolutiva muy diferente a la de la mayoría de los otros señoríos castellanos, porque la promulgación de leyes que permitirían a los enfiteutas el rescate del dominio directo, previo pago de forma colectiva al titular del señorío, dio lugar al acceso definitivo a la propiedad plena a la totalidad de los enfiteutas y, por consiguiente, a la desaparición del dominio directo que había permanecido intacto en manos de la casa señorial hasta 1893.

\begin{abstract}
It is a known fact that in Andalucía. Castilla, or La Mancha during the Ancient Regime, the lords of the land maintained complete control over the land which was lent to different cultivators on a short-term rental basis. In these cases, the abolition of the rights of the lords signified only the loss of their exclusive
\end{abstract}


rights, private and prohibitive, for they consolidated as private property their respective patrimony. However, one can also find cases in the area of Castilla as well as in the dominions of Ontur, Albatana, and Agramón, holdings of the estate of the marquisate of Espinardo where the evolution followed lines parallel to those experienced by the lands of the dominions of the Old Corona de Aragón, and even in Galicia. The introduction of the emphyteutic relation as the only manner to colonize and establish rents in the aforemention dominions, made possible a dynamic evolution that was very different from that of the majority of the other castillian dominions because the enactment of laws that would permit the emphyteutics to rescue direct authority, with the collective payment to the titular head of the dominion, opened the possibility of definitive acces to all property by all emphyteutics, and therefore, to the disappearance of the direct domination which had remained intact in the hands of the land-holding class until 1893.

\section{Introducción}

Uno de los temas que más interés viene suscitando últimamente entre los estudiosos del siglo XVIII es precisamente el de la importante labor de recolonización interior iniciada por la monarquía española durante ese siglo, dentro de un ambicioso plan de recuperación económica trazado por los ilustrados. Generalmente se habla más porque es mejor conocida y más importante, de la obra de Carlos III, pero también en la primera mitad del XVIII surgieron iniciativas en este sentido.

Al igual que ocurriera en territorios del antiguo Reino de Valencia, también en territorio castellano habrían de llevarse a cabo tareas de colonización en la primera mitad de ese siglo. Es el caso de los señoríos de Ontur y Albatana, territorios pertenecientes al marquesado de Espinardo, cuyo titular inició en 1751 una amplia operación de colonización de unas tierras donde la casi total despoblación fue una constante probablemente desde la Reconquista y donde la expansión demográfica y la recuperación económica habría de tardar en llegar. Ontur y Albatana figuran en el censo de Tomás González con dos habitantes (1) y no parece que desde el siglo XVI hasta que se iniciara la repoblación a mediados del XVIII experimentaran cambios revelantes. Entre ambos momentos, la crisis económica del siglo XVII debió contribuir sin duda al mantenimiento de tal estado de cosas.

La colonización de los señoríos de Ontur y Albatana tiene un claro precedente en la proliferación de establecimientos enfitéuticos ex-novo en el Bajo Segura durante la primera mitad del setecientos (2) y una relación casi directa con la obra colonizadora del Cardenal Belluga en la zona pantanosa de Orihuela y con el asentamiento de colonos llevado a cabo por el duque de Arcos en los carrizales de Elx. En las Pías Fundaciones la tarea colonizadora se inició 
realmente en 1730; el sistema escogido fue la enfiteusis con partición de frutos (1/4)y el pago de seis cuartos por tahúlla para el mantenimiento de la red de azarbes y acequias mayores (3). La coincidencia sería mucho mayor con el asentamiento de colonos en los carrizales de Elx; en este caso, sobre un territorio amojonado en 1730 por el señor, el rey aprobaba en 1748 las condiciones para establecer un nuevo poblado junto a las tierras pantanosas que iban siendo colonizadas. El duque de Arcos se reservaba, para sí y sus herederos, el dominio directo sobre la laguna, aguas, yerbas, tierras cultivadas y casas del término de Carrizales, cediendo el dominio útil a sus habitantes, de acuerdo con la relación enfitéutica establecida entre ambos (4). En la Cédula Real concedida en Aranjuez al duque de Arcos en 1748, se especifican unas condiciones prácticamente idénticas a las que tres años después se otorgarían al marqués de Espinardo en los establecimientos de Albatana y Ontur.

Según consta en la transcripción de escritura original, don Pedro de Zambrana y Faxardo compró en 1562 por cuarenta mil ducados «las villas de Ontur y Albatana con su jurisdicción civil y criminal y mero y misto imperio y con horca y quchillo, y con sus fuentes de aguas abrevadero pastos prados y hegidos y con un molino de pan harinero y con las casas y fortaleza de Ontur y con las casas llanas de la villa de Albatana y viñas y con la venta y tierras de Mojon blanco de regadio y secano y con el Jaraiz tinajas y cepos de prision que estan en las dichas villas y con todo el termino y tierras a ellas anexas y pertenecientes segun y de la manera que estaban amojonadas» (5). Los señoríos habían pertenecido a Lope de Chinchilla, vecino de Hellín, quien por virtud de sentencia dictada por el Tribunal de Inquisición tras ser condenado por los delitos de herejía y apostasía, vio confiscados sus bienes, que poco después serían de nuevo puestos en venta por el Real Fisco y rematados en pública almoneda por el citado Zambrana. Con posterioridad, el citado Pedro Zambrana y Manuel Zambrana vendieron de nuevo el señorío en 1592, por un precio de cuarenta y dos mil ducados, a don Alonso de Entenza Pacheco. En 1751, don Diego Alonso de Entenza, Fajardo y Vera, marqués de Espinardo, era el poseedor, entre otros mayorazgos, del que fundaran don Alonso de Entenza Pacheco y doña Aldonza Cascales, al que pertenecían las villas de Ontur, Albatana y Mojón Blanco, con la jurisdicción civil y criminal, mero y mixto imperio y todas las tierras comprendidas en su término. Más tarde, el heredamiento de Agramón, un caserío del municipio de Hellín, limítrofe con el de Albatana, se incorporó al marquesado. Agramón constituyó un vínculo, fundado en Hellín en 1577 por don Francisco María Valcárcel, y habiendo casado una sucesora suya con uno de los marqueses de Espinardo, se incorporó al marquesado (6) siguiendo un proceso de colonización similar al de Ontur y Albatana.

\section{La relación enfitéutica como forma de colonización}

En la Real Cédula fechada en Aranjuez en 1751, quedaban fijadas las condiciones 
por las que el marqués de Espinardo, mediante contrato enfitéutico, podía iniciar el establecimiento de campesinos.

Las relaciones de producción establecidas en la Real Cédula para Ontur y Albatana, son idénticas a las que existían en todos aquellos señoríos valencianos donde el extrañamiento de la población morisca había hecho posible que los señores fijaran nuevas condiciones a los campesinos repobladores. Además de la posesión de la jurisdicción, elemento básico y definitorio de coerción extraeconómica, el marqués de Espinardo disponía de una serie de derechos sobre la tierra, regalías y otras facultades preeminentes que constituían los mecanismos esenciales de extracción de ingresos. Los señoríos de Ontur y Albatana presentan, teniendo como elemento central la figura de la enfiteusis, una situación de propiedad compartida entre el marqués, que poseía el dominio directo y los enfiteutas, poseedores del dominio útil. Estos estaban obligados al pago de un canon anual en productos (partes alícuotas de la cosecha denominadas particiones) y de cantidades fijadas en dinero. Estaban también obligados a pagar luïsmo (cantidad en metálico que se pagaba al señor cada vez que se vendía una tierra o una casa) y también quedaban contempladas en las condiciones, la fadiga (derecho preferente del titular del dominio directo para consolidarlo con el dominio útil y conseguir la plena propiedad), el derecho de tanteo y la facultad de comiso por parte del señor cuando se incumplían las condiciones establecidas en el contrato enfitéutico. El enfiteuta, siempre que respetara el pacto contraído en las condiciones de establecimiento, disponía libremente del dominio útil, pudiendo comprar, vender, o dar en herencia casas y tierras.

Junto a estos derechos sobre la tierra, el marqués disfrutaba además de los ingresos derivados de los derechos de monopolios o derechos exclusivos y privativos. En este caso eran los monopolios de almazara, mesón, carnicería, tabernas, molino harinero, horno y tiendas de todo género, aunque permitiendo a los enfiteutas tener horno propio en sus casas para cocer el pan necesario para su consumo y poder moler donde quisieran la aceituna y cualquier tipo de granos, incluso fuera de la jurisdicción.

En concreto, las condiciones fijadas en la Real Cédula eran en resumen las siguientes:

\section{Cargas en especie}

En regadío:

- 1/5 de todos los frutos en granos.

- 1/7 de la uva y la aceituna.

- 1/5 de la barrilla.

- 1/5 del lino y el cáñamo.

En secano:

- 1/10 de los frutos en granos.

- 1/9 de la uva y la aceituna. 
- 1/11 de la barrilla.

- 1/5 del producto de los árboles frutales.

Cargas en dinero

- 11 reales vellón por tahúlla al año, por las cuatro tahúllas en donde podían edificar casa.

- 2 reales de vellón anuales por cada quince varas, por edificar casas en las tierras de labor.

- 18 reales por tahúlla en las cuatro tahúllas señaladas para huerta, jardín o cercado.

- 4 maravedíes de vellón por tahúlla para monda de azarbes mayores que se hacía por cuenta del marqués.

\section{Otras condiciones}

- Por cada cien tahúllas podían sembrarse cuatro para alimento de animales de labor y por tanto exentas de carga.

- Las tierras de secano en el momento de ser ocupadas y que pasasen a ser de regadío, quedaban sujetas a las particiones de las tierras de regadío.

- El marqués permitía que cada enfiteuta pudiera hacer en sus tierras aceñas, norias o balsas. En este caso la proporción de las participaciones era de 1/8 tanto en granos como en uva y oliva, 1/6 en la morera, 1/7 en la fruta, lino y cáñamo.

- Prohibición de sembrar arroz.

- Obligación de sembrar olivos, viña y morera.

- Las casas ya edificadas en el pueblo en el momento del establecimiento quedaban exentas de toda contribución.

- El producto de las penas en que incurriesen los enfiteutas sería repartido en tres partes iguales: una para los gastos de justicia, otra para el propio marqués y la tercera para el denunciante (7).

En el heredamiento de Agramón, según Real Facultad de 4 de enero de 1802, se concedió licencia para establecer también en enfiteusis. En síntesis, las condiciones obligaban al pago de $1 / 7$ de todos los frutos, tanto en regadío como en secano, y una cantidad en metálico por las casas. Habría una modificación en el pago del canon, según escritura de reducción otorgada por el marqués de Espinardo en 16 de enero de 1823.

El primer aspecto que llama la atención poderosamente lo constituye el hecho de que el marqués de Espinardo, como señor jurisdiccional y solariego de Ontur y Albatana, recurriese a la enfiteusis como forma de colonización en un mayorazgo castellano. Como señala Clavero, «posibilidad jurídica de fundación de un mayorazgo sobre el derecho enfitéutico puede también encontrarse en la doctrina mayorazguista castellana, pero lo definitorio en ésta es el carácter de incompatibilidad que establece entre el mayorazgo del dominio feudal y cualquier derecho real, más aún vinculado, del colono a la tierra amayorazgada» (8). No obstante, aunque el grado de permisividad a la hora de llevar a cabo enajenaciones, 
fuera mayor en el mayorazgo valenciano o catalán, tampoco debió ser práctica inusual en el mayorazgo castellano.

Sea como fuere, lo cierto es que la Real Cédula precisa este aspecto arbitrando la solución a cualquier tipo de incompatibilidad que pudiera existir entre mayorazgo y contrato enfitéutico al señalar:

«Yo por la presente confirmo, y apruebo, é interpongo á todas, y cada una de ellas mi Authoridad Real, y quiero, y mando, que valgan, y sean firmes, bastantes, y valederas, en quanto fueren conformes, y no excedieren de lo contenido en esta mi Carta, sin embargo del dicho vuestro Mayorazgo, y cualesquiere clausulas, y condiciones de él, Leyes, fueros, y Derechos, usos y costumbres, expeciales, y generales, hechos en Cortes, ó fuera de ellas, que en contrario de esto sean, ó ser puedan, que para en quanto a ello toca, y por esta vez dispenso, y lo abrogo, y derogo, caso, y anulo, y doy por ninguno, y de ningun valor, quedando en su fuerza, y vigor, para en lo demas adelante. Y para este efecto, y no otro alguno, aparto, y divido del dicho Mayorazgo, y de sus clausulas, y condiciones las mencionadas tierras, y las hago libres, no obligadas, ni sugetas á vinculo, ni restitución alguna, con tanto que sean propias de dicho vuestro Mayorazgo, porque mi intención y voluntad, no es de perjudicar en ello a mi Corona Real, ni otro Tercero alguno, que no sea de los llamados á el, y con los dichos censos perpetuos, y lo demás que os diere por las citadas tierras, queden respectivamente unidos, subrogados é incorporados en el expressado vuestro Mayorazgo, á que como vá referido pertenecen, para lo que estén perpetuamente con las mismas clausulas, vinculos, gravamenes, y condiciones, con que estaban las dichas tierras, y lo están los demás sus bienes, que yo desde ahora los he por unidos, subrogados é incorporados en el dicho vuestro Mayorazgo...» (9).

Un segundo aspecto, igualmente interesante, es el que hace referencia al mayor o menor grado de dureza fijado en las condiciones para los campesinos establecidos. Buena parte de la bibliografía valenciana que ha estudiado el problema de la repoblación de señoríos tras la expulsión de los moriscos a partir de 1609, ha insistido sobre el hecho de que las nuevas cartas pueblas sirvieron para actualizar las prestaciones de los nuevos enfiteutas, incrementando e introduciendo donde no lo había, la partición de frutos en la nueva relación enfitéutica. La operación habría significado, en consecuencia, una refeudalización del señorío valenciano, por cuanto en las nuevas relaciones señor-vasallo, el primero pudo llegar a imponer unas nuevas y más exigentes condiciones. Sin embargo, a medida que van apareciendo nuevas monografías, cobra mayor sentido la idea de que probablemente los señores no estuvieron, en la mayoría de los casos, en condiciones de imponer, sino que más bien la enfiteusis fue la única 
forma de atraer nuevos pobladores (10). En un reciente trabajo, Peset Reig, se pregunta precisamente cómo es posible que los señores pudieran imponer una refeudalización en las tierras despobladas del ámbito valenciano, cuando la realidad es que tuvieron que ofrecer la posibilidad del contrato enfitéutico, frente al arrendamiento por ejemplo, para lograr atraer campesinos (11).

En el caso de la repoblación de Ontur y Albatana los campesinos repobladores prefirieron igualmente la enfiteusis, que les convertía en semipropietarios, a otra forma de establecimiento. La Real Cédula no puede ser más explícita en este sentido cuando señala que «á causa de que los antecedentes Posseedores no han tenido facultad para establecer, perpetuamente dichas tierras, que son muchas, y de superior calidad, como tambien las aguas con que pueden regarse, no han hallado personas con possibilidad, y medios para su cultivo, que quieran tomarlas por tiempo limitado rezelando, que los Dueños hagan novedades, y pierdan sus intereses, de que han resultado no poderse establecer Vecindarios, segun corresponden á la proporcion, y bondad del termino, quedar sin cultivo, ni aprovechamiento lo mas de él, porque las fuerzas, y caudal de un Posseedor, no bastan para las expensas precisas de los edificios, y demás que se necessitan, y assimismo traer mayor imposibilidad de reparar estos grabes daños, que redundan no solo contra la subsistencia de dichos Mayorazgos, sino es en contra de la causa publica de dichos Pueblos; Y respecto de que diferentes Personas, os han ofrecido, establecerse en dichas Jurisdicciones, siempre que se les den tierras a censo emphiteutico, vaxo las condiciones que teneis dispuestas...» (12).

A la vista del texto, es evidente que señor y enfiteutas estaban interesados en el establecimiento de la relación enfitéutica; el señor porque no tiene que hacer ningún gasto para poner en cultivo sus tierras incultas y se asegura la única forma de obtener unos sustanciosos ingresos fijos y los campesinos, que se niegan a establecerse mediante el tipo de contrato normal en esta parte de Castilla, el arrendamiento a corto plazo, porque el contrato enfitéutico establecido entre la casa señorial y la familia campesina -no entre particulares- les ofrecía plena seguridad a la hora de realizar nuevas inversiones necesarias para la puesta en cultivo. Es difícil hablar por tanto de refeudalización en este caso y más difícil todavía establecer por ahora si la situación de estos enfiteutas de Ontur y Albatana era peor que la que pudieran tener los arrendatarios de otros territorios cercanos, tanto en el realengo como en el señorío.

La distribución del terrazgo sí fue diferente a la de los señoríos valencianos repoblados. Allí la tierra se distribuyó por lo general, aunque hubo excepciones (13), en lotes iguales y casi siempre de modestas dimensiones; ello dio lugar a la constitución ex-novo a partir de 1609 de unas comunidades rurales con un elevado grado de homogeneidad. Por el contrario, en Ontur y Albatana el señor «invitó a varios vecinos de los pueblos inmediatos para que las tomaran baxo dicho contrato; a virtud de este llamamiento los abuelos de los actuales labradores de la expresada villa (Ontur), acudieron a ella, y recibieron de D. Alonso de Entenza Faxardo y Vera, el numero de tahullas de tierra en regadio, y fanegas de secano que cada uno quiso...» (14). 
$\mathrm{Al}$ igual que ocurriera en los señoríos existentes en territorio de la antigua Corona de Aragón y a diferencia de lo que aconteció en el resto del conjunto de señoríos del ámbito castellano y andaluz, sobre este esquema general preexistente, los acontecimientos políticos del siglo XIX vendrían a incidir de forma negativa para el marqués de Espinardo, a pesar de sus vanos intentos por conservar lo esencial, la propiedad de la tierra en Ontur, Albatana y Agramón, a cambio de renunciar a sus derechos exclusivos, privativos y prohibitivos. La fuerte resistencia antiseñorial encabezada en Ontur por los enfiteutas más ricos, se concretaba en el hecho de considerarse como propietarios plenos de unas tierras que estaban sujetas a separación de dominios pero que ellos, lógicamente, se negaban a reconocer. Los decretos abolicionistas habrían de permitir finalmente a los enfiteutas de Ontur y Albatana el acceso a la plena propiedad, mediante la posibilidad legal de redimir el censo enfitéutico, consolidando así el dominio útil y el directo. Como consecuencia, la estructura del dominio útil se habría de corresponder con la estructura de la propiedad resultante en los últimos años del siglo XIX. Con ello se trasmitía también la diferencia de estructura del dominio útil y por tanto de clases existente en el período final del Antiguo Régimen.

\section{Repercusiones del decreto de 6 de agosto de 1811}

La enorme trascendencia del decreto de 6 de agosto de 1811 en la configuración de las estructuras de propiedad agraria en España, ha sido ya puesto de relieve en varias ocasiones (15). No conviene olvidar claros precedentes de signo abolicionista como el Memorial Ajustado del Consejo de Castilla de 1776, la Real Cédula de 25 de febrero de 1805 y los debates de los diputados en Cádiz cuyas conclusiones servirían para informar el decreto de 1811 (16). En éste quedaban «incorporados a la nación todos los señoríos jurisdiccionales de cualquier clase y condición que sean» $\left(\operatorname{art.~} 1^{\circ}\right)$; se fijaba que el gobierno y la administración de justicia pasaba en todos los lugares a manos de la Corona $\left(\operatorname{art.~} 2^{\circ}\right.$ y $3^{\circ}$ ); quedaban «abolidos los dictados de vasallo $\mathrm{y}$ vasallaje y las prestaciones, así reales como personales, que deban su origen a título jurisdiccional, a excepción de los que procedan de contrato libre en uso del sagrado derecho de propiedad» $\left(\right.$ art. $\left.4^{\circ}\right)$; también quedaban excluidos todos los derechos exclusivos, privativos y prohibitivos $\left(\operatorname{art} .7^{\circ}\right)$. El punto central era el conocido artículo $5^{\circ}$ por el cual «los señoríos territoriales y solariegos quedan, desde ahora en la clase de los demás derechos de propiedad particular, si no son de aquellos que, por su naturaleza, deban incorporarse a la nación, o de los en que no se hayan cumplido las condiciones con que se concedieron, lo que resultará de los títulos de adquisición». En consecuencia, como se apuntaba en el artículo $6^{\circ}$, «los contratos pactos o convenios que se hayan hecho en razón de aprovechamientos, arriendo de terrenos, censos u otros de esta especie celebrados entre los llamados señores y vasallos, se deberan considerar desde ahora como contratos de particular a particular» (17). 
La abolición de señoríos jurisdiccionales significaba un cambio en la situación existente de mezcla de aspectos jurisdiccionales y territoriales en muchos casos. Todos estaban de acuerdo, incluso los ilustrados y el propio Fernando VII (puesto que de hecho dejó en vigor el decreto de 1811) en que todas las facultades jurisdiccionales que tenían los señores debían unirse al estado liberal, pero al tiempo se pactaba con ellos que los aspectos territoriales del señorío quedarían intocados preservando así la propiedad territorial que los distintos titulares pudieran tener en sus respectivos señoríos y garantizándoseles un derecho de propiedad privada de cuño burgués.

En la casi totalidad de los casos en Andalucía, Castilla o La Mancha, las condiciones del pacto fueron extraordinariamente beneficiosas para los antiguos señores. Por el contrario, en Ontur y Albatana su titular había de perder el patrimonio territorial de sus señoríos.

A pesar de la claridad y precisión de conceptos que los señores territoriales querían encontrar en el artículo $5^{\circ}$ del decreto de 1811 , donde parecía claro que quedaban contemplados sin ningún género de dudas los derechos de propiedad privada, lo cierto es, como señala Moxó, que la redacción del artículo era confusa (18). Si bien es cierto que fijaba la conversión del señorío territorial en propiedad privada, también dejaba abierta la posibilidad excepcional de que aquellos señoríos solariegos en que se demostrase que habían sido adquiridos ilegalmente por su titular, fueran incorporados a la nación. Además, tampoco se recogía en el texto qué parte estaba obligada a demostrar la legitimidad de la adquisición, si los señores o los titulares del dominio útil.

Por estas razones, muchos pueblos de señorío del ámbito valenciano iniciaron pleitos legales contra sus titulares y de forma generalizada se negaron a seguir satisfaciendo al señor cualquier tipo de prestaciones. Si por el mismo decreto, argumentaban los enfiteutas, se había declarado reunido el dominio directo de molinos, hornos y demás artefactos pertenecientes al Real Patrimonio, con el dominio útil, por la misma razón debía consolidarse el dominio directo con el útil en los terrenos, edificios y artefactos poseídos hasta ese momento por los señores. Si estos no exhibían algún documento en el que quedara patente el conocimiento del Rey, es que el señorío había tenido un origen ilegal y, en consecuencia, su desaparición quedaba contemplada en el artículo $5^{\circ}$ del decreto. Aunque como bien argumentaba el marqués de Astorga en su representación enviada a las Cortes en 1820 «quieren esos ayuntamientos y vecinos que la propiedad o dominio directo de ninguno de estos terrenos pueda jamás volver a incorporarse a la misma nación; porque en tal caso no podían negarse, ni excusarse a pagar a esta las mismas rentas, prestaciones o cánones, que hasta ahora han satisfecho a los señores territoriales...». Lo que en realidad pretendían era que «...el dominio directo o propiedad de estos terrenos y fincas, que hasta ahora han pertenecido a los titulados señores, se consolide con el dominio útil que ellos disfrutan» (19). 
Exactamente la misma situación se creó en el señorío de Ontur donde el ayuntamiento inició en 1837 un pleito contra el señor territorial, D. Joaquín Ma . Fernández de Córdova, conde de Sástago y marqués de Espinardo, instándole a que presentase todos los documentos necesarios para calificar la naturaleza y clase de señorío, negándose mientras tanto a satisfacer las prestaciones estipuladas en la Real Cédula de 1751.

Básicamente, la argumentación del Procurador Síndico y ayuntamiento constitucional de Ontur, se limitaba a señalar que la documentación presentada por el señor territorial era «insuficiente de todo punto para señalar la clase de señorío y ver si se han cumplido en él las condiciones con que se concedió; obligación que pesa única y precisamente contra dicho señor; quien hasta que la lleve no tiene derecho con arreglo a la ley tres de mayo de mil ochocientos veinte y tres, a seguir percibiendo las prestaciones que hasta presente ha recibido del pueblo, puesto que de los títulos exividos solo aparece que dichas dos villas se vendieron por los Zambranas en mil quinientos noventa y dos a D. Alonso Tenza con su jurisdicción, mero y mixto imperio, horca y cuchillo; pero ni se acredita el título de egresión, ni el dominio de los vendedores; y menos el tracto sucesivo hasta el actual poseedor; de consiguiente con respecto a Ontur no ha presentado título alguno...» (20).

Por el contrario, el representante del señor argumentaba en su escrito que el señorío de Ontur quedaba contemplado en la clase de propiedad particular porque la escritura de venta otorgada a favor de don Pedro Zambrana debía «tenerse y reputarse como título primordial y primitivo de la egresión (...) y considerarse constituido desde la fecha de ésta; sin atender por ningun motivo a la forma en que pudo esta hacerse anteriormente...» (21). Las razones de la negativa de los enfiteutas a satisfacer el canon eran otras bien distintas, en opinión del representante del marqués: «está fuera de disputa que a sus moradores no puede ocultarse baxo de ningun concepto, que el canon en frutos que pagan, es una consecuencia inmediata de la constitucion de este (censo enfitéutico), y que jamas podrian eximirse de pagarlo, por solo negarse a ello; que es la unica razon que hasta ahora han presentado (...) y que por tan frívolo pretexto se estinguiese el Enfiteusis, consolidandose el dominio directo con el util; y que los labradores de Ontur adquirieran ambos sin haver hecho desembolso alguno» (23). La verdadera contradicción existente entre las pretensiones de los enfiteutas y lo que realmente se contemplaba en el artículo 5. ${ }^{\circ}$ del decreto se apuntaba también en el mismo escrito: «quieren que el señorio de esta Villa sea incorporable a la Corona, suponiendo gratuitamente que se separaría de ella en su principio por nueva liveralidad del Monarca, y no como recompensa de grandes servicios, o en equivalencia del valor que por el se diera; y al mismo tiempo intentan que una vez incorporado a la Corona, esta se los ceda sin preceder sacrificio alguno de parte de ellos en su favor; pensamiento a la verdad descavellado y que solo puede existir en la acalorada imaginacion de los referidos Labradores, que consultando sus intereses privados, miran las cosas de diferente modo a como son en si» (24). 
En el escrito del promotor fiscal del partido judicial de Hellín, tras incidir en los mismos argumentos anteriores y calificar las razones del representante del ayuntamiento de «congeturas inberosimiles y reflexiones desnudas de todo fundamento» y señalar que «los Ayuntamientos de las Villas de Albatana y Agramon (...) han manifestado de modo inequiboco su conformidad en reconocer como legitimas las prestaciones conque contribuyen a el señor Marqués», opinaba que debía dejarse «definitivamente este pleito en el estado en que se alla, declarando justas y legitimas las prestaciones con que al señor Marques de Espinardo contribuyen los vecinos» (25).

Como era lógico, el fiscal de S. M. concluía en julio de 1838 que, por su naturaleza, el señorío no debía ser incorporado a la nación y, en consecuencia, quedaba reducido a la clase de propiedad particular con arreglo al artículo 5. ${ }^{\circ}$ del decreto de 6 de agosto de 1811 (26). En 1840, el Tribunal Supremo declararía desierta la apelación interpuesta por la villa de Ontur (27).

Lo cierto es que la sentencia dictada por el Tribunal Supremo no hacía más que confirmar lo que venía siendo norma habitual en muchos pleitos -aunque también hubo sentencias a favor de los municipios- desde que el 27 de marzo de 1813 en el mantenido por las villas de Elx y Crevillent contra su titular el conde de Altamira «se sentó doctrina en el sentido de que el elemento territorial y solariego de los señoríos jurisdiccionales pasaba a la categoría de propiedad privada y estimó, al propio tiempo, que no eran los señores obligados a presentar los titulos acreditativos de su derecho a las percepciones sino los enfiteutas quienes habían de probar la ilegalidad de estas» (28).

\section{La redención de censos enfitéuticos y las nuevas estructuras de propiedad}

En el marco de una situación política determinada, además de las medidas desvinculadoras, como la ley de mayorazgos de 27 de septiembre de 1820, la ley de redención de censos de 3 de mayo de 1823, reafirmada por la de 26 de agosto de 1837, así como la ley Madoz, constituyeron un punto esencial en el conjunto de medidas abolicionistas, al tiempo que debe considerarse como un hecho clave por cuanto supuso la desaparición de la propiedad señorial y la consolidación de la pequeña y mediana propiedad.

La legislación liberal, por tanto, acabaría por abrir definitivamente el cauce legal a los enfiteutas para redimir sus censos y rescatar el dominio directo consolidándolo con el dominio útil. Con ello, a diferencia de lo que ocurriera en otros señoríos territoriales castellanos o andaluces donde las tierras estaban cedidas en arrendamiento a corto plazo, desaparecía para el marqués de Espinardo la posibilidad de conservar su patrimonio territorial en Ontur, Albatana, al tiempo que se consolidaban de iure unas nuevas estructuras de propiedad en correspondencia con la estructura general del dominio útil existente al producirse la redención. 
Estructura general del dominio útil en Ontur y Albatana. 1862.

Albatana

\begin{tabular}{ccrcr}
$\begin{array}{c}\text { Grupos } \\
\text { (Ha) }\end{array}$ & \multicolumn{2}{c}{ Pum. } & \multicolumn{1}{c}{ Superficic } \\
\hline 1 & 118 & 38.5 & 40.24 & 1.7 \\
$1-3$ & 69 & 22.6 & 119.57 & 5.1 \\
$3-5$ & 17 & 5.6 & 67.33 & 2.8 \\
$5-10$ & 38 & 12.4 & 272.41 & 11.4 \\
$10-30$ & 38 & 12.4 & 663.57 & 28.0 \\
$30-50$ & 19 & 6.2 & 688.80 & 29.0 \\
$50-100$ & 6 & 2.0 & 414.72 & 17.4 \\
$100-300$ & 1 & 0.3 & 109.83 & 4.6 \\
\hline Total & 306 & $\mathbf{1 0 0 , 0}$ & $\mathbf{2 . 3 7 6 , 4 7}$ & 100,0 \\
\hline
\end{tabular}

Ontur

\begin{tabular}{ccccc} 
Grupos & \multicolumn{2}{c}{ Propietarios } & \multicolumn{2}{c}{ Superficie } \\
\hline (Ha) & Núm. & $\%$ & Total & $\%$ \\
1 & 76 & 34,0 & 21.66 & 0.7 \\
$1-3$ & 42 & 18,7 & 73.37 & 2.4 \\
$3-5$ & 15 & 6.7 & 55.21 & 1.8 \\
$5-10$ & 30 & 13.4 & 218.56 & 7.2 \\
$10-30$ & 30 & 13.4 & 534.13 & 17.6 \\
$30-50$ & 13 & 5.8 & 529.44 & 17.4 \\
$50-100$ & 13 & 5,8 & 873.06 & 28.8 \\
$100-300$ & 5 & 2.2 & 733.83 & 24.1 \\
\hline Total & 224 & 100,0 & $3.39,26$ & 100,0 \\
\hline
\end{tabular}

Fuente: A. H. P. Albacete, Amillaramientos de Ontur y Albatana, 1862.

Elaboración propia.

Conviene precisar que el mecanismo de la redención de censos enfitéuticos fue más lento de lo que en principio pudiera pensarse. En caso contrario no se explican las leyes de $27 \mathrm{de}$ febrero de 1856 (aclarando la de 1 de mayo de 1855), la de 11 de julio de 1878 y la de 23 de julio de 1885 , todas referidas a esta materia. 
Para explicar la lentitud en el rescate del dominio directo, Peset Reig argumenta la escasez de dinero de muchos campesinos o la falta de interés en la redención por tratarse de cargas poco gravosas al estar devaluadas con el paso del tiempo (29). En el caso de los señoríos de Ontur, y Albatana, donde la redención de censos se efectuó de forma colectiva en 1893, distribuyendo mediante derrama el costo de la misma, fue claramente debido a la primera razón. El ejercicio real de sus derechos por parte del señor, la cuantía de las particiones y el cobro del luismo fijadas en la escritura de arriendo de los derechos de Agramón en 1877, así aconsejan pensarlo al menos.

\section{Conclusiones}

Es un hecho conocido que en Andalucía, Castilla o La Mancha, los señores territoriales mantenían durante el Antiguo Régimen el pleno dominio sobre la tierra, que era cedida a diferentes cultivadores en régimen de arrendamiento a corto plazo. En estos casos, la abolición de derechos señoriales significó únicamente la pérdida de sus derechos exclusivos, privativos y prohibitivos, pero consolidaron como propiedad privada sus respectivos patrimonios. Pero también pueden encontrarse en el ámbito castellano casos, como el de los señoríos de Ontur, Albatana y Agramón, pertenecientes al mayorazgo del marquesado de Espinardo, donde la evolución siguió líneas paralelas a las que experimentaron los territorios de señorío en la antigua Corona de Aragón en incluso en Galicia. La introducción de la relación enfitéutica, como única forma de colonizar y rentabilizar los señoríos mencionados, posibilitó una dinámica evolutiva muy diferente a la de la mayoría de los otros señoríos castellanos, porque la promulgación de leyes que permitirían a los enfiteutas el rescate del dominio directo, previo pago de forma colectiva al titular del señorío, dio lugar al acceso definitivo a la propiedad plena a la totalidad de los enfiteutas y, por consiguiente, a la desaparición del dominio directo que había permanecido intacto en manos de la casa señorial hasta 1893.

\section{NOTAS}

1. GONZÁLEZ, T. Censo de población de las provincias y partidos de la Corona de Castilla en el siglo XVI, Madrid, I.N.E., 1982, 2 vols.

2. BERNABÉ GIL, D. Tierra y sociedad en el Bajo Segura (1700-1750), Alicante, Universidad de Alicante - Caja de Ahorros Provincial de Alicante, 1982, pp. 121-187.

3. Véase LEÓN COSTA, T. «Aportación al estudio de la colonización de la Vega Baja del Segura», Anales de la Universidad de Murcia, vol. XXI, núm, 3-4, 1962-63, pp. 98-140. MILLÁN, J. Transición y reacción en el sur del País Valenciano. La formación del capitalismo agrario y los orígenes del carlismo: Orihuela, 1680-1840, Tesis doctoral inédita, Valencia, 1982.

4. RUIZ TORRES, P. «Propiedad de la tierra y estructura de clases en el campo valenciano 
durante los siglos XVIII y XIX: los carrizales de Elx», Estudis d'Història Contemporània del País Valencià, Valencia, Departamento de Historia Contemporánea, núm. 1, 1980, pp. 91-93. 5. A. H. P. Albacete, Sección Audiencia Civil, Caja 155, legajo 1.

6. MADOZ, P. Diccionario Geográfico-Estadístico de España y sus posesiones en Ultramar, Madrid, 1846-1850.

7. A. H. P. Albacete, Condiciones con que se han de otorgar las Escrituras, ó contratos de las tierras, que como suyas propias, y de sus Mayorazgos ha de dar á censo Emphiteutico, con cargo de Luitmo, y Fatdiga, el marqués de Espinardo, en los términos de sus Villas de Ontur, y Albatana, y término de Mojon blanco, á diferentes Vecinos de ellas, y otros, con aprobación, y facultad de el Rey nuestro Señor (Dios le guarde), Aranjuez, 15 de junio de 1751, Sección Audiencia Civil, Caja 155, legajo 1.

8. CLAVERO, B. Mayorazgo, propiedad feudal en Castilla (1369-1836), Madrid, siglo XXI, 1974.

9. A. H. P. Albacete, Condiciones..., pp. 24-25.

10.ROMERO GONZÁLEZ, J. Propiedad agraria y sociedad rural en la España mediterránea. Los casos valenciano y castellano en los siglos XIX y XX, Madrid, Publicaciones del Ministerio de Agricultura, serie Estudios, 1983, pp. 356-357.

11.PESET REIG, M. Dos ensayos sobre historia de la propiedad de la tierra, Madrid, E.D.E.R.S.A, 1982, pp. 195-196.

12.A. H. P. Albacete, Condiciones..., pág. 2.

13.CASES RUIZ, M. C. Aproximación a la demografía y a la estructura de la Propiedad en Tárbena (Alicante) tras la expulsión de los moriscos, Valencia, 1983.

14.A. H. P. Albacete, Sección Audiencia Civil, Caja 155, legajo 1.

15.GIL OLCINA, A. La propiedad señorial en tierras valencianas, Valencia, del Cenia al Segura, 1980, Cap. VII.

RUIZ TORRES, P. «Señorío, propiedad agraria y burguesía en la revolución liberal española», comunicación presentada al coloquio O liberalismo na Peninsula Ibérica, Lisboa, 1981.

ROMERO GONZÁLEZ, J. Propiedad agraria..., op. cit.

16.GIL OLCINA, A. «Crisis y transferencia de las propiedades estamental y pública», $L a$ propiedad rústica en España y su influencia en la organización del espacio, Alicante, 1980.

17.MOXO, S. La disolución del Régimen señorial en España, Madrid, 1965.

18.Ibídem, pág. 55.

19.Representaciones de diferentes Grandes de España a las Cortes para que se declare debérseles amparar en la posesión de sus rentas, especialmente en el Reino de Valencia, Madrid, 1820.

20.A. H. P. Albacete, Sección Audiencia Civil, Caja 155, leg. 3.

21.Ibídem.

22.Ibídem.

23.Ibídem.

24.Ibídem.

25.Ibídem

26.A. H. P. Albacete, Sección Audiencia Civil, Caja 155, leg. 3.

27.A. H. P. Albacete, Sección Audiencia Civil, Caja 155, leg. 2.

28.GIL OLCINA, A. «Crisis y transferencia...», op. cit.

29.PESET REIG, M. Dos ensayos..., op. cit. pág. 103. 


\section{APÉNDICE DOCUMENTAL}

\section{DOCUMENTO I}

Condiciones con que se han de otorgar las Escrituras, o contratos de las tierras, que como suyas propias, y de sus Mayorazgos ha de dàr à censo Emphiteutico, con cargo de Luitmo, y Fatdiga, el Marques de Espinardo. En dos terminos de sus Villas de Ontur, y Albatana, y termino de Mojon blanco, à diferentes Vecinos de ellas, y otros, con aprobacion, y facultad de el Rey nuestro Señor (Dios le guarde).

DON FERNANDO por la Gracia de Dios. Rey de Castilla, de Leon, de Aragon, de las dos Sicilias, de Jerusalem, de Nabarra, de Granada, de Toledo, de Valencia, de Galicia, de Mallorca, de Sevilla, de Cerdeña, de Cordoba, de Corcega, de Murcia, de Jaen, de los Algarbes, de Algezira, de Gibraltàr, de las Islas Canarias, de las Indias Orientales, y Occidentales, Islas, y Tierra Firme del Mar Occeano, Archiduque de Austria, duque de Borgoña, de Brabante, y Milàn, Conde de Abspurg, de Flandes, Tiròl, y Barcelona, Señor de Vizcaya, y Molina.

Por quanto por parte de Vos Don Diego Alonso de Entenza, Faxardo, y Vera, Marquès de Espinardo, me ha sido hecha relacion, sois poseedor, entre otros Mayorazgos de el que fundaron Don Alonso de Entenza, Pacheco, y Doña Aldonza Cascales, à el que pertenecen las Villas de Ontur, Albatana, y Mojon blanco, con la Jurisdiccion Civil, y Criminál, Mero, Mixto imperio, y todas las tierras comprehendidas en su Termino, assi de riego, como de secano; y à causa de que los antecedentes Posseedores no han tenido facultad para establecer, perpetuamente dichas tierras, que son muchas, y de superior calidad, como tambien las aguas con que pueden regarse, no han hallado personas con possibilidad, y medios para su cultivo, que quieran tomarlas por tiempo limitado, rezelando, que los dueños hagan novedades, y pierdan sus intereses, de que han resultado no poderse establecer Vecindarios, segun corresponden à la proporcion, y bondad del termino, quedàr sin cultivo, ni aprovechamiento lo mas de èl, porque las fuerzas, y caudal de un Posseedor, no bastan para las expensas precisas de los edificios, y demàs que se necessitan, y assimismo traer mayor impossibilidad de reparar estos grabes daños, que redundan no solo contra la subsistencia de dichos Mayorazgos, sino es contra la causa publica de dichos Pueblos; Y respecto de que diferentes Personas, os han ofrecido, establecerse en dichas Jurisdicciones, siempre que se les dèn tierras à censo perpetuo emphiteutico, vaxo las condiciones, que teneis dispuestas, obligandose solamente à cumplirlas, precediendo licencia mia, que el tenor de dichas Condiciones es el que se sigue.

Es condicion, que todas las tierras pertenecientes à el Marqués de Espinardo, que son de los vinculos, y mayorazgos, que se comprehenden en las dos Villas de Ontur y Albatana, y 
termino de Mojon blanco; sus tierras, termino, y jurisdiccion, y que en virtud de Real Facultad se han de dar à censo, han de estàr, y quedàr gravadas à censo perpetuo, con cargo de Luitmo, y Fatdiga, y Derecho Emphiteutico, à favor de dicho Marquès de Espinardo, segun se contendrà en los Capitulos, y Condiciones subsequentes, sin que por ningun titulo, causa, ni razon pueda variarse assi por dicho Marquès, ni sus Administradores, que son, ò en adelante fueren, como tampoco por los Caesalistas Emphiteutas, que aora sean, y les sucedieren, contra su tenor en modo alguno de dichas condiciones, baxo la pena de nulidad de el instrumento publico, ò secreto, que se hiciere, y de caer en comiso la propiedad, ò propiedades, sobre, que se intentasse dicha variacion, ò alteracion.

Que todos los Censalistas, que aora, ò en adelante fueren, han de someterse con renunciacion de su propio Domicilio, ò Vecindario à las Justicias, que lo sean de dichas Villas, por lo que hace à las causas, y negocios, tocantes y pertenecientes à dichas Daciones, aunque vivan en otros Pueblos fuera de la Jurisdiccion.

Que ningun Censalista ha de poder fabricar Almazara, Meson, Carnicerìa, Taberna, Molino harinero, Horno publico, ni Tienda de ningun genero, ni especie, porque todo esto es unicamente facultativo à el Marquès de Espinardo, como dueño propietario de dichas tierras; pero sì, se les permitirà à dichos Censalistas, que para su uso propio, y cocer el pan necessario para su consumo, puedan tener Horno en sus casas, ò barracas; y assimismo se prohibe a los Censalistas, que no puedan vender, ceder, ni en modo alguno enegenar las yervas naturales, y restrojos de qualquiera esquilmos, yà sean de granos, hortalizas, y rizales, porque todas han de quedar à beneficio del Marqués de Espinardo, menos las que dichos Censalistas necessiten para sus precisos averìos.

Que como và dicho en la antecedente condicion, no han de poder dichos Censalistas fabricar con pretexto alguno en sus heredades Almazara, porque unicamente pertenece esta regalìa à dicho Marquès de Espinardo; pero si se les permite, que puedan moler su aceytuna en las Almazaras, que tuvieren por mas conveniente, aunque sea en otras fuera de la Jurisdiccion; y lo mismo se entiende en la molienda de todos generos de granos.

Que siendo precisso, que pasten los ganados de los abastos publicos, y assimismo los ganados de las personas, que comprassen las yervas de dichos terminos, yà sean forasteros, o yà vecinos, para que no se experimenten perjuicios en los plantados, sembrados, ò demàs labores, no se permitirà à los Abastecedores tengan mas porcion de ganado, que aquella muy precissa para el abasto; y a los Ganaderos forasteros, ò vecinos, se les castigarà con todo rigor de Justicia en cualquier caso, que executen algun perjuicio con sus ganados en dichas haciendas, ò labores, aunque sea en las suyas propias, esto interin no se arreglan Ordenanzas, è imponen penas para los dañadores, como se practica en la huerta de Murcia, y otras partes, assi para los ganados, que hagan daños en los frutos, como para los que lo hagan en las fuentes, ò acequias, y brazales de el riego.

Que dichos Censalistas Emphiteutas, que aora, y adelante fuessen, han de contribuir, y pagar perpetuamente à dicho Marquès de Espinardo la quinta parte de todos los frutos en granos, que se sembrassen en las tierras de riego, afectas à dichos censos, y en las tierras de secano, han de contribuir, y pagar, assimismo perpetuamente la decena parte de dichos frutos en granos; y por lo que mira à los de vino, y aceytuna han de pagar perpetuamente la septima parte de los frutos de los que cogiessen en las tierras, que gocen de el beneficio de el riego, y en las que sean de secano han de pagar la novena parte de dichos frutos de vino, y aceytuna; que de el de barrillas si sembrassen algunas en tierras de riego, pagaràn la quinta parte de las que cogiessen, $\mathrm{y}$ de las que sembrassen, y cogiessen en tierras de secano, pagaràn 
la oncena parte; de el cañamo, y lino sembrado, y cogido en las tierras de riego pagaràn la quinta parte de dichas dos especies de frutos.

Que para la mejor, y mas facil exaccion, y cobranza de el dicho quinto, con que han de contribuir, y pagar todos los Censalistas en los frutos de trigo, cebada, panizo, garvanzos, avena centeno, frisuelos, lantejas, y otros de esta classe, cogidos en las tierras de el riego, y la decima parte de la misma classe de dichos frutos, sembrados, y cogidos en las tierras de secano: el quinto de el cañamo y lino que cogiessen en las tierras de dicho riego; y juntamente la parte que corresponde en los frutos de hortalizas, y yervas de cebada, alfalfas, ù otras: han de preceder las formalidades y circunstancias, que se mencionan en la condicion siguiente.

Que luego, è inmediatamente, que dichos Censalistas tiviessen en sus eras trillados, espicazados, y limpios todos los frutos de los referidos granos separados, y amontonados los que hayan cogido de las de secano, daràn puntual aviso à la perta de dicho Marquès de Espinardo, para que con su precissa asistencia, y no en otra forma se hayan de medir dichos frutos en la misma hera separados, como queda dicho los de el riego de los de el secano, y reconocida la parte que de dichos frutos deba percibir dicho Marquès de Espinardo, esta parte, ò partes, serà de cuenta de dichos Censalistas el conducirla, y ponerla en las casas, y graneros de dicho Marquès; y dicha conduccion se ha de practicar, inmediatamente, que se hayan medido los referidos frutos; y esto mismo se deberá entender con todos los demàs esquilmos.

Que para la cobranza de el de la uba ha de passar la parte de dicho Marquès, con assistencia de los respectivos dueños, à las viñas de estos luego que estèn en parage de cortarse la uba, y determinado antes el como se ha de terragear; esto es, si ha de ser por hilos, por capazos, ò por cargas, pues de todos modos se ha terrageado hasta aora, debiendo ser dicho terrageo à voluntad de dicho Marquès, ò su parte por obiar assi los muchos fraudes, que pueden cometerse, como se ha experimentado. De manera, que la parte de dicho Marquès empezarà a conta por la parte, que le pareciere conveniente; ya sea por hilos, ya por capazos, ò ya por cargas, el que se siga, y haga numero de siete, quedarà señalado, o apartado, y anotado por de dicho Marquès, $\mathrm{y}$ en esta misma forma se proseguirà en toda la demàs uba criada, $\mathrm{y}$ producida por las tierras de riego; y en las de secano se observarà esta misma regla, y condicion, cobrando de cada nueve hilos, cargas, ò capazos, uno, y assi en todas las demás viñas respectivamente en uno, y otro terrageo.

Que para la cobranza del fruto de la oliva, en atencion à que desde primeros de Noviembre se empieza à caer de los arboles, y no es practicable el terrageo por el mucho tiempo, que tarda la recoleccion de el todo dicho fruto: es condicion, que en los dias primeros de el mes de Diciembre de cada año, se han de nombrar dos inteligentes tassadores: uno, por parte de dicho Marquès, y otro por la de los Censalistas Emphiteutas; y dichos dos Peritos passaràn à tassar las fanegas de oliva, que cada uno de los dichos Censalistas tuviesse en sus respectivas haciendas; y hecha la tassacion de toda la oliva, daràn dos relaciones juradas, y firmadas de ambos, una à la parte de el Marquès, y otra à los Censalistas, ò à la persona, que estos nombrassen para que la reciba; y en vista de dicha relacion, en la que estarán comprehendidas todas las fanegas de aceytuna, que à cada uno de por sì de dichos Censalistas se hayan tassado, la parte de dicho Marquès señalarà a cada uno las fanegas, ò partes, que deban pagar, la que cogeràn, como assimismo la suya, en sus propios tiempos, y no en otros, como se dirà en su lugar.

Que assi el expressado fruto de la oliva, como el de la uba, luego, que por la parte de dicho Marqués, se aya señalado, ò anotado, y que se aya cogido, cortado, ò arrancado por 
los mismos Censalistas, estos à su costa, ò por sì mismos, han de conducir dichos frutos à los lagares, y cassas de dicho Marquès de Espinardo, executando esto mismo en todos los demàs frutos.

Que el referido fruto de la uba, y el de la aceytuna, no han de poder dichos Censalistas cortarle, ni recogerle, hasta que por parte de dicho Marquès se aya dado licencia para este efecto, y el que la cortàre, ò cogiesse antes, serà condenado à pagar el terrageo doble, y con su hacienda assegurar, que los vinos, ò aceytes, que se perdiessen de los de dicho terrageo, ha de pagarlos à los precios que corriessen, $\mathrm{y}$ se vendiessen los demàs de dicho Marquès, pues esta condicion respecta à solo obiar, que corten los frutos sin la debida razon, lo que causa perderse los referidos frutos; bien porque sobre este particular, se prevendrà lo correspondiente en las Ordenanzas, que se han de formar.

Que la cobranza, y terrageo de el panizo, se ha de practicar por capazos, en las mismas hazas, y con assistencia de ambas partes, y el que aya tocado à lo de dicho Marquès le conduciràn los Censalistas à su costa a las cassas, y graneros de dicho Marquès, como queda dicho, haviendose terrageado de cada cinco capazos uno, en todas tierras de riego, y de cada diez en las de secano.

Que el quinto del lino, y cañamo, le han de pagar en garva, ò garvilla, contando por treznales, ò por heras, sin sacudir antes la simiente, que esta tambien pertenece à dicho Marquès, y dichos Censalistas lo conduciràn à las balsas, ò sitios señalados por dicho Marquès.

Que el fruto de barrilla se ha de cobrar, y terragear en el mismo oyo, con assistencia de ambas partes interessadas, sin la que, ò su licencia no podrà ningun Censalista sacar de los oyos dicha barrilla, $\mathrm{y}$ lo contrario haciendo, estarà obligado à pagar el terrage doble.

Que el fruto de la uba, y oliva, le han de coger, y cortar precissamente antes que cojan, ni corten dichos Censalistas los demàs frutos, que de ellos les pertenezcan, pues hasta tanto, que los que à dicho Marquès hayan tocado, los hayan puesto dichos Censalistas à su costa en las casas de el referido Marquès, no deberàn cortar, ni arrancar fruto alguno, y lo contrario haciendo, deberàn incurrir en la pena de cincuenta pesos por la primera vez, ciento por la segunda, y el entero comisso de sus tierras por la tercera, entendiendose esta misma condicion en qualquiera fraude que cometan con qualquiera otro genero de frutos.

Que respecto à que una de las condiciones de las Escripturas de estos censos, serà el que hayan de plantar los dichos Censalistas plantones de moreras, ò morales, como mas bien se dirà en su lugar, deberàn los referidos Censalistas pagar, y contribuir con una onza de hoja por cada cinco onzas de las que tuviere, precediendo antes una formal tassacion por los peritos, è inteligentes, nombrados à este intento, baxo las mismas circunstancias, que para la tassacion de el fruto de la oliva; pero que dicha onza, ù onzas de hoja, que por razon de dicho quinto hayan tocado à el Marquès de Espinardo, si èste, ò su parte se conviene la dexarà à dichos Censalistas; y de no, la beneficiarà por sì; y si la dexasse à algun Censalista, pagarà este setenta y cinco reales de vellon por cada onza de hoja, assi de morera, como de moral, y en su defecto dos libras de seda fina, y buena.

Que haviendose experimentado, que algunos Labradores de los que oy hay, yà sea por malicia, ò yà por ignorancia, han intentado pagar la parte que à dicho Marquès ha pertenecido de aquellas parbas, que han tenido mas inferiores, y demàs baxa calidad de granos; ha de ser condicion invariable, que cada parba que trillassen, y limpiassen, se haya de cobrar enteramente la parte que à dicho Marquès perteneciesse, y lo mismo se observarà en todo 
genero de esquilmos; y si alguno, ò algunos de dichos Censalistas intentasse contravenir, ò contraviniesse en parte, ò en todo a lo prevenido por esta condicion, incurra inviolablemente en la pena de veinte y cinco pessos por la primera vez, cincuenta por la segunda, y el entero de comisso de todas sus tierras, por la tercera.

Que como se ha dicho, ninguno de los Censalistas pueda juntar, ò mezclar las miesses, o esquilmos, que hayan producido las tierras de el riego con las de el secano, y lo contrario haciendo, y justificando que sea este tan gravoso fraude, incurriràn los culpados en la pena de el de comisso de las tierras de el riego, y secano, que huviessen producido los esquilmos que se huviessen mezclado, quedando por esta razon el dominio util, unido con el directo que se reserva dicho Marquès de Espinardo.

Que respecto à que dichos Censalistas necesitan de algunas yervas para la manutencion de sus precisos averìos, se les permitirà, que de cada cien tahullas puedan sembrar quatro tahullas de yervas, de cebada, alfalfa, ù otros, pero de estos han de pagar en dinero efectivo la parte que (precedida tassacion) tocasse a dicho Marquès de Espinardo, y lo mismo de cualquiera otros esquilmos, que à causa de los temporales, sea preciso segarlos en yerva.

Que además de las quatro tahullas señaladas en la condicion antecedente para poder sembrar alfalfas, ù otras yervas, se les señalarà otras quatro por cada cien tahullas para que en ellas puedan labrar, ò fabricar las Barracas, ò Palacios que necessiten para su propio uso, con la precisa condicion de que por cada una de dichas quatro tahullas, ò las ocupadas en dichos edificios, han de pagar once reales de vellon en San Juan de cada un año.

Que cualquiera Censalista; que quisiere fabricar alguna casa, ò casas en las tierras de su labor de secano, ò en el monte inmediato en los de los terminos de las expresadas Villas lo pueda hacer, pagando dos reales de vellon en San Juan de cada un año por cada quince varas de territorio, en quadro, pagando à proporcion si necessitasse mas terreno.

Que las casas, que al presente tienen fabricadas en el cuerpo de dichas villas, han de quedar unidas al cuerpo de la dacion de las expresadas tierras, que aora se les han de dar por haverlas fabricado, solo al fin de tener que recoger sus averìos, y aperos de la labòr, por cuya razon, y considerar las anexas à dichas tierras, y labores, no se les impone pension, ò censo separado.

Que todas las expresadas casas qualesquiera otros edificios, tierras de labòr, viñas y todos los demàs plantados, han de quedar sugetos à la contribucion de el Luitmo, y Fatdiga en qualquiera caso de venta, cambio, enagenacion, ò traspasso.

Que todas las tierras, que al presente no son de riego, si en adelante lo fuessen, y se le diese dicho Marquès de Espinardo con las aguas que aora tiene, ù otras que nuevamente aya descubierto, han de quedar sugetas à la paga, y demàs condiciones, que las que actualmente se riegan, contribuyendo en todos frutos con la parte, ò partes, que como à tierras de riego le corresponda; y si dicho nuevo riego se les diese despues de otorgadas las Escrituras de las Daciones, que aora se han de practicar, deberà el Censalista acudir à la Escrivanìa en donde estè su contrato, y anotar con testimonio de el Escrivano, la porcion de tierra à que nuevamente se le aya dado riego, acotandose, y obligandose à la paga de el censo que le corresponde, y à todas las demàs condiciones.

Que si alguno de los expresados Censalistas quisiere (yà sea antes de otorgar la Escritura de su Dacion, ò yà sea despues de otorgada) hacer alguna Aceña, ò Noria, ò sacar, y descubrir alguna fuente de agua para con balsa, ò sin ella, regar las tierras de su Dacion, pueda libremente hacer dichos edificios, y sacar las aguas que reconozca haver en las 
expressadas tierras de su Dacion; y en atencion à que ha de tener la obligacion de mantener en todos tiempos corrientes, y usuales, no solo los referidos edificios de fuente, balsa, y noria; sì, tambien las acequias, brazales, azarbes, mayores y menores, y los precissos escorredores para el saneamiento de las tierras; ha de ser, y es condicion, que de cada ocho fanegas de trigo, cebada, centeno, garvanzos, abena, $\mathrm{y}$ demàs semillas ha de pagar una de las que cogiesse en dicho nuevo riego; $\mathrm{y}$ del vino, $\mathrm{y}$ aceyte, baxo de las reglas arriba dichos, ha de pagar, yà sea por hilos, capazos, cargas, y fanegas de cada ocho una; que de la hoja de moral, ò morera ha de pagar de seis onzas una; que de las frutas que huviesse, sean del genero que fuessen, ha de pagar de cada siete arrobas una; que de lino y cañamo, ha de pagar de cada siete treznales, ò garvillas uno; que de las mieses, que sea preciso segarlas por no poderse aprovechar mas que para yervas, ha de pagar en la misma forma; que de las quatro tahullas que se señalan para huerta, jardín, ò cercado ha de pagar à razon de à diez y ocho reales por tahulla; que para la labranza, y percepcion de los expresados frutos, y terrages se han de observar las mismas reglas, y circunstancias que con los demàs Censalistas que obtienen tierras de riego. $\mathrm{Y}$ es condicion, que luego que el expressado Censalista haya regado sus tierras, si las aguas que à su costa ha sacado, y dadoles curso fuessen en tal abundancia, que puedan proseguir regando las tierras que se siguen à las de dicho Censalista, haya de darles paso por sus mismas tierras, y dexarlas que passen à regar las que se siguen, yà sean de otros Censalistas, y yà de la labor de el expresado Marquès de Espinardo, y en ningun tiempo pueda cegar, ni tapar dichas fuentes, y si lo hiciesse; havriendolas el Marquès a su costa, pagarà el Censalista como en el de mas riego antiguo que tiene dicho Marquès.

Que todas las demàs tierras que se regassen como las referidas aguas han de pagar los terrages à dicho Marquès en la forma que todas las de el demàs riego, contribuyendo con el quinto, ò demàs partes señaladas, y que corresponden à todo genero de mieses, y frutos.

Que ningun Censalista pueda sacar de su hera, viña, olivar, ò qualquiera otra hacienda, ningun otro esquilmo de los que à èl toca, sin que antes haya conducido à su costa à las casas, ò sitios señalados por dicho Marquès, ò su Apoderado, la parte, ò partes que de dichos esquilmos le haya tocado, y lo contrario haciendo, incurran en la pena de veinte y cinco pesos por la primera vez, cincuenta por la segunda, y el entero comisso de la tierra en que se haya causado el fraude, por la tercera vez.

Que con ningun titulo, razon, ni motivo alguno han de poder dichos Censalistas sembrar arroz en ninguna de sus tierras, por lo noscivo que es à la salud publica dicho esquilmo; y si alguno contraviniese à esta condicion, incurra inviolablemente en la pena de cien pesos de multa; y si reincidiese segunda vez se han de declarar, y dàr por de comisso el todo de sus tierras.

Que todos los Censalistas han de cuidar, y cultivàr todas las tierras de su dacion, segun estylo, y costumbre de buen Labrador; y las han de sembrar, segun, y como es costumbre en la huerta de Murcia; no dexando sin sembrar dos años seguidos las expressadas tierras de riego, antes si, que lleven todos los esquilmos, que su bondad y buena calidad les permita.

Que siempre y cuando, que por cualquiera de los Censalistas se pretenda vender el todo, ò parte de sus tierras, casas ò barracas, fabricadas en dichas tierras, ò en las poblaciones de las referidas Villas, ha de preceder licencia formal de dicho Marquès, ò sus Apoderados; por si dicho Marquès las quiere por el tanto; $\mathrm{y}$ en caso de no, les darà licencia para que en virtud de ella puedan practicar la venta, enagenacion, ò traspaso, otorgando la Escritura, ò Escrituras ante el Escrivano Ordinario de dichas Villas, insertando en ella la referida licencia para su validacion, pagando antes, como se ha dicho, el vendedor el Luitmo, 
que es la decima parte de el valor de la alhaja que vende, y el comprador la Fatdiga: entendiendose lo mismo en otro qualquier instrumento de trueque, cesion, ò en qualquiera modo de enagenacion, quedando en dicho instrumento el comprador obligado à observar, guardar, y cumplir todas las condiciones de este establecimiento, baxo las penas impuestas en ellas, y en caso de contravenir à esto, ò verificarse haver hecho algun instrumento publico privado, papel simple, ò contrato verbal, han de caer en comiso las tierras y demàs propiedades, contenidas en dicha cesion, instrumento, papel, ò trato verbal como và dicho. NOTA. Que la cesion, ò traspaso, no se entiende quando se hace con el motivo de dote à hijo, ò hija, ò para que un hijo ponga casa separada de la de sus padres, pues en este caso no deberà contribuir en cosa alguna, y si quando dicho traspasso se hace à otra persona, sea con el motivo que fuesse, pues no siendo de padres à hijos, ò por muerte de los primeros à sus precisos herederos en qualquiera otro caso, deberàn contribuir con el derecho del Luitmo. Y Fatdiga, como se ha dicho.

Que sobre las tierras, y demàs propiedades de dicho Marquès, que aora ò en adelante se diesen à censo, no han de poder los Censalistas, que las possean, ò posseyeren imponer sobre ellas con pretexto alguno Vinculo. Capellanìa, Pìa Memoria, Patronato, Censo, ni otra semejante impossicion, ni las han de poder vender, donar, ceder, ni otra semejante impossicion, ni las han de poder vender, donar, ceder, ni enagenar, ni legarà Religion, Inquisicion, ni otra Comunidad; ni tampoco à eclesiastico Regular, ò Secular, aunque sea de las Ordenes Militares, ò goce de otro fuero Eclesiastico; porque siempre han de recaer, y estàr dichas tierras en personas sugetas à la Jurisdiccion Real Secular, para obiar por este medio los litigios, y competencias que suelen originarse; y por el consiguiente impossibilitar la practica de esta, y demàs condiciones, y en caso de faltar à cualquier cosa, ò parte de lo que và expecificado en esta Condicion, à demàs de la nulidad, que subendrà, han de caer en comiso riguroso dichas propiedades, que se verifique haverlas destinado el Censalista en alguno de los expressados prohividos casos.

Que si (Dios no lo permita) qualquiera de los Censalistas cometiesse delito de Lessa Magestad Divina, ò Humana, por el mismo hecho se ha visto caer en comiso las propiedades que tuviesse, y quedar unido el dominio util de el Censalista con el directo de dicho Marquès.

Que siempre, que por parte de dicho Marquès se quisiere hacer remedida de las tierras establecidas, lo ha de poder practicar, y si de ellas resultase algun excesso de tierras que tenga, y possea de mala fe el Censalista, las restituirà à dicho Marquès, y assimismo pagarà en este caso el costo de la medida que se hubiese hecho, y en la misma forma los quatro mrs. por tahulla, de las que se hallasen de dicho excesso por razon de las mondas, y limpias de dichas acequias, como no pasen de diez años, pues los que passasse de estos no deberà satisfacerlos.

Que dichos Censalistas han de procurar tener la casa, ò casas, que huviessen fabricado en dichas Villas, ò en sus haciendas, bien reparadas, para que no se arruinen, y las referidas tierras, viñas y olivares, labradas y cultivadas à uso, y costumbre de buen Labrador, porque si se experimentasse lo contrario, han de caer en comiso, bastando para ello la declaracion, y juramento de dos Peritos judicialmente, pero si fuesse ocasionada la falta de cultivo, por razon de peste, guerra ò inundacion de rio, ò rambla en aquel territorio, en estos casos, ò cualquiera de ellos sossegado, ò apartado de sus inconvenientes, deberàn dichos Censalistas dentro de tres años, ò antes, poner en perfecto cultivo dichas tierras, y reparar las referidas causas, baxo las mismas penas. 
Que ninguna persona con pretexto alguno ha de poder entrar, ni los Censalistas permitir, que entren en sus tierras, con el motivo de espigar, ni recoger las mieses, que quedan en los restrojos de trigo, y cebada, assi de esta especie, como de otro esquilmo, por haverse esperimentado en varias ocasiones, que con este motivo han usurpado, y llevandose las tales personas de los treznales muchas porciones, y lo mismo de otros esquilmos, y en caso de contravenir à esta Condicion, con sola la aprehension, y no haviendola, con la justificacion necessaria se le ha de condenar en las multas que se tengan por convenientes por las Justicias de dichas Villas, y à proporcion de los granos, ò efectos, que ayan recogido (que han de perder) han de satisfacer las costas que se huviessen causado en dicha justificacion, ò aprehension, y estar, y pasar por las condiciones, ù ordenanzas, que sobre este particular se formen en adelante para el mejor methodo, y seguridad de dichas tierras, incurriendo en las mismas penas los Censalistas, en caso de haverles justificado la permission para la entrada en sus tierras, y recoleccion de espiga, y demàs frutos.

Que todo el estiercol, y vasura, que los Censalistas hiciesen en sus casas, y heredades no han de poder venderlo para fuera de la Jurisdiccion de dichas Villas, porque precisamente lo han de consumir en sus tierras, ò en las demàs de los Censalistas, sugetos a dicho Marquès; pues lo contrario haciendo han de incurrir en la pena de tres pesos, y de reintegrar otra tanta porcion de estiercol, ò vasura en dichas tierras, en el termino, que para ello se les asigne, y se les permitirà precedida licencia puedan en las calles, y plazas de dichas Villas recoger el estiercol, ò vasura, que en ellas se haga, como es practica en todos los Pueblos.

Que siempre, y quando, que por descuido, ò malicia de algun Censalista, ocasionasse con los riegos, labores ò escabaciones algun daño en los quixeros de los azarbes mayores, ò menores, y demàs edificios, como en las canales, puentes y partidores, han de ser condenados à reparar à su costa el daño con las costas, y por razon de multa tres pesos cada vez que lo executen.

Que todos los arboles frutiferos, ò infrutiferos, cañas, mimbres, ù otros semejantes, que estuviessen en los xiqueros de los azarbes mayores, que quedan nombrados, han de ser, y beneficiarse por dicho Marquès; pero los referidos arboles, y demàs que se criassen, ò plantassen en los xiqueros de los edificios menores, ò particulares de las tierras, que comprehendan à cada Censalista por confrontacion, ò dentro de ellas, quedaran à su beneficio, pagando la quinta parte de la fruta, que produzcan dichos arboles frutiferos, que la parte impuesta en el corte de los infrutiferos en especie de dinero, y à justa tassacion en la forma que va prevenido, sin poder hacer dichos cortes hasta que preceda èsta, baxo la pena, lo contrario haciendo de tres pesos, à demàs de dicho quinto.

Que en caso de que cualquier Censalista quisiesse por su diversion, ù otro motivo semejante hacer algun huerto, cercandolo de tapias, ò bardizas en las tierras que tuviesse, y sean de las contribuyentes, no ha de poder exceder este cercado de quatro tahullas, para lo que ha de preceder formal licencia de parte de dicho Marquès, y deberà pagar en lugar de el sexto de fruto à veinte y dos reales de vellon por cada una tahulla de las que assi ocupe, por los dias de San Juan; y en caso de que no preceda dicha licencia, ha de incurrir en la pena de tres pesos, y ser condenado à la demolicion, ò desbarato de dicha cerca.

Que luego que se reconozcan las tierras dadas, y establecidas à cada Censalista, por los Peritos, que se nombrassen por parte de dicho Marquès; declarando estos las que son buenas para plantarse, lo han de hacer cada uno de dichos Censalistas, sin dilacion alguna de morales, moreras, oliveras, ò viñas, conforme lo que requiera, y la calidad de la dicha tierra reciba aquel genero de arbolado que los inteligentes declaren; y à sus tiempos han de ingerirlos 
à lo mas tarde dentro de dos años, y desde que estè en parage de producir hoja util las moreras, ò morales, deberàn contribuir con la quinta parte de la hoja, que produzcan segun và prevenido, $y$ en caso de que se experimente de que passados dichos dos, ò tres años, no han ingerto dichas moreras, à costa de el Censalista lo podrà mandar hacer dicho Marquès; y no lo permitirà coja hoja alguna de dichas moreras, hasta el expressado tiempo de los tres años, que se le conceden libres de este fruto, aprovechandose de ella dicho Marquès, y por lo respectivo à las oliveras, ò viñas, han de procurar su cultivo, y labor à uso, y costumbre de perfectos Labradores, pudiendoles en la firma forma apremiar à ello, y a su costo por parte de dicho Marquès.

Que todos los Censalistas pagaràn sin fraude dolo ni detencion alguna los Diezmos que à cada uno de por si le tocarse de el entero de sus frutos, (que como ha sido estilo hasta oy) y todo baxo de las censuras, y penas impuestas à los malos pagadores de Diezmos: que en atencion à que dexando al cuidado de los Censalistas la limpia, y monda de las acequias, y azarbes principales; nunca podràn estar limpios dichos edificios, ni en el tiempo que mas lo necessitan, pues cada uno lo haria quando pudiesse, ò quisiesse: es condicion precisa, que la limpia, y monda de las fuentes, acequias madres, y azarbes mayores han de limpiarse de orden, y cuenta de el dicho Marquès de Espinardo, y sus successores, contribuyendo los Censalistas con quatro maravedises de vellon por cada tahulla de las que tenga en su dacion, ò que possea por haverlas comprado, ò heredado à otros, y estos quatro mrs. se han de pagar en San Juan de cada un año.

Que las acequias, y azarbes mayores son, y se entienden todos los edificios, que el Marquès ha hecho, y abierto à su costa, para la conduccion de las aguas à las tierras, y el saneamiento de ellas.

Que las tahullas de los Censalistas, que han sacado el agua à su costa, no se comprehenden en la contribucion de los dichos quatro mrs. en atencion a ser del cargo de los Censalistas que han costeado el riego à sus tierras la limpia, y monda de todos los edificios comprehendidos en dichas tierras; y por la misma razon seràn suyos todos los arbolados que huviesse en dichos edificios, pagando al Marquès de Espinardo la octava de sus frutos.

Que para la contribucion de los quatro mrs. de vellon por tahulla, para las mondas de los azarbes mayores, que se hacen de cuenta de dicho Marquès, no se ha de incluir en la medida de las tierras de los Censalistas, las que ocupassen los caminos, azarbes mayores, ni los deificios de aguas muertas, comunes à todos los hacendados; pero si deberà incluirse las entradas, sendas, regaderas, ò brazales pertenecientes à el uso de las tierras.

Que de las aguas vivas ciertas, que tiene el Marquès de Espinardo, para el riego de las tierras, se formarà por parte de dicho Marquès un repartimiento perpetuo subsistente, y equitativo, y las aguas no perenes, ni ciertas quedaràn al advitrio de dicho Marquès, para su mas arreglada distribucion, segun la mas, ò menos necesidad, y caudal de agua, que traxessen los edificios, y correspondiese à la necesidad del dia, para cuyo fin, y evitar las questiones, y perjuicios, que ocasionasse la codicia, acudiràn los Censalistas à la Administracion, ò sitio destinado para ello, donde se les repartirà el agua, que correspondiesse à vista de la necesidad de los demàs Censalistas, sin que con ningun titulo, accion, ni pretexto pueda alguno de ellos à su arvitrio usar de dichas aguas, porque han de estàr, y passar precisamente por dicho reparto, y en caso de contravenir à èl, pagaràn las costas, y daños, que ocasionassen à otro tercero, à demàs de la pena, que por dicho arreglamiento se imponga. 
Que si sucediesse, que algun Censalista, ò Censalistas sembrassen dos esquilmos juntos en algun bancal, ò bancales han de pagar el quinto de ambos esquilmos à dinero ò en especie (si fuere grano) baxo las penas, que quedan establecidas en las demás condiciones.

Que si algunas tierras sembradas de trigo, ò cebada, se llenassen de yervas, de suerte, que resuelvan venderlo para las cavallerìas, ò consumirlo en las propias, no lo han de poder hacer, sin que preceda licencia de dicho Marquès, por quien se ha de hacer tassar, y deberàn pagar los Censalistas la parte que corresponda de su importe en dinero, ò en especie, à voluntad de dicho Marquès; y lo contrario haciendo, incurriràn (à demàs de la restitucion del fruto, y costas) de la pena de dos pesos, por cada vez, que lo hiciere, y si llegase a tercera vez serà la pena al arvitrio de la Justicia.

Que ninguno de los Censalistas pueda vender por menor en su casa, ò barraca, ni otra parte alguna vino, aceyte, vinagre, ni otro genero de comestible de los que se vendan por menor en las Tiendas de qualquiera de las Villas, por ser en perjuicio de las regalìas de el Marquès; pero sì podràn vender por mayor de los frutos, que cojan en sus heredades; y en la misma forma se les prohive puedan establecer, ò poner Figones, ni Pastelerìas, todo baxo la pena de veinte pesos, por cada vez, que lo executen.

Que todas las referidas penas pecuniarias, que vàn expressadas en los Capitulos, y Condiciones antecedentes, y las que se estableciessen para el govierno de las aguas, y de la huerta, con aprobacion de S. M. y Señores de su Real Camara, se han de dividir en tres partes iguales: La una, para los gastos de Justicia; otra, para el Marquès de Espinardo, y la tercera, para el Denunciador, y si fuese à queja de parte, lleve esta la de dicho Denunciador.

Que baxo las condiciones, que quedan expressadas, se han de otorgar de oy en adelante perpetuamente todas las Escripturas de tierras, pertenecientes à dicho Marquès de Espinardo, obteniendo para ello Real Cedula de S.M. (Dios le guarde) con incersion de ellas, la qual se protocolarà en la Escrivanìa de el Escrivano, que lo es Originario de dichas Villas, y en la que se hallan protocolados los demás instrumentos de ellas, y de dicha Real Cedula, y Condiciones, se formaràn impressos, que legalizados en toda forma, se entregarà uno à cada Censalista terrateniente, otorgandose por su parte; y en virtud de la licencia que ha de preceder de dicho Marquès, ò su Administrador.

Suplicandome, que siendo este medio el unico de restablecerse dichas Poblaciones, y aprovecharse las referidas tierras, y aguas; construir Iglesias en que se coloque à su Magestad Sacramentado, y aumentar considerablemente los productos, y rentas de dicho Mayorazgo, y mis Reales Haberes; sea servido concederos licencia, y facultad, y à vuestros subcessores, precedido el examen necessario de todos los hechos expressados, y aprobar las Condiciones arriba insertas, para que establezcan, y distribuyan todas las Tierras de los referidos terminos de dichas Villas de Ontur, Albatana y Mojon blanco, asi de riego, como de secano, y las aguas de ellos, que actualmente hai, y de nuevo se descubran, dandolas à censo perpetuo emphiteutico, con las dichas calidades, y otorgando à este fin las Escripturas convenientes, ò como mi merced fuesse, sobre lo qual, y para informarme de la utilidad, ò perjuicio que de esto se seguiria al citado Mayorazgo, y sus poseedores, por Cedula de veinte y uno de Mayo del año proximo passado; mandè à mi Corregidor de la Ciudad de Murcia, o su Alcalde Mayor Lugar Theniente en el dicho Oficio, que llamada, y oìda la parte del inmediato subcesor al dicho Mayorazgo, hoyiesse informacion de lo referido, la qual con su parecer, y traslado autorizado de la Escriptura original de su Fundacion 
embiasse, para que vista, se proveyesse lo que conveniesse. Y el Licenciado Don Gonzalo de Rioxxa Valadares, Alcalde Mayor de la expressada Ciudad, la hubo en la forma referida, y fue traìda, y presentada en el mi Consejo de la Camra, y de todo ello resulta, que Vos el dicho Don Diego Alonso de Entenza, Marquès de Espinardo, sois posseedor del Mayorazgo, que fundaron Don Alonso de Entenza Pacheco, y Doña Aldonza Cascales, por el testamento, que otorgaron en la Ciudad de Murcia, à veinte y tres de Agosto de mil quinientos noventa y seis, ante Juan de Montalbo, Escrivano del Numero, y Juzgado de ella, baxo de cuya disposicion fellecieron, al que pertenecen las expressadas Villas de Ontur, Albatana, y Mojon blanco, y todas las tierras comprehendidas en su termino, assi de riego, como de secano, todas las quales vistas, y reconocidas por Christoval de Exea, y Joseph Gomez, Personas inteligentes, nombradas para este efecto, declararon, que el termino, y jurisdiccion de la Villa de Ontur, comprehenderà cerca de una legua en quadro, en la qual habrà como quatro mil fanegas de tierra de diferentes calidades, toda la mas inculta, aunque alguna corta cantidad se està laboreando por diferentes Labradores, que llamados de Vos, y en virtud de palabra que les ha dado de darles las expressadas tierras (precedida mi Real facultad) y otras à censo emphiteutico, baxo de las condiciones que quedan referidas, se ha establecido, assi en dicha Villa de Ontur, como en la de Albatana, labrando Casas à su costa, y una Hermita, para que les digan Missa y expliquen la Doctrina Christiana: Que otra parte de tierra de los expressados terminos se compone de Sierras: y montes pedregosos, que nunca podrán producir mas utilidad, que la de la Leña para quemar: Que la demàs tierra que dexan dicha por estàr inculta, serà de muchissima utilidad à los Mayorazgos, siempre que se cultive, y beneficie por los Labradores, y lo será mas con el crecido beneficio del riego, por el agua que Vos estais sacando, y habeis sacado à vuestras expensas, para con ella regar una crecida porcion de tierra, la que con este beneficio producirà à mas de sesenta reales por fanega en dicho riego, pero en secano, producirà à mas de diez reales cada una fanega, en lo que se reconoce el mucho aumento que recibiràn los dichos Mayorazgos, quando lo que producen oy es solamente la leña de Pino Carrasqueño, y las Atochas, y tambien el certissimo valor de las yerbas, las quales las toman en arrendamiento los mismos Labradores, por dar à un tiempo à sus ganados los rastrojos de sus Mieses, pues sin ellos no arrendarìan las dichas yerbas: que el termino, y jurisdiccion de Albatana, se compone de poco mas de un quarto de legua en quadro, el de Mojon blanco es de menos de un quarto de legua, y uno, y otro les parece puede haber mas de dos mil fanegas de tierra, comprehendidos los Cerros, Collados, y Cañadas, y dicha tierra es de todas calidades, pero la menos mala, serà mejor con el riego que Vos le bais dando: Que por lo que hace à la Iglesia que hai, y se puede hacer en dicha Villa de Ontur, declaran, que los Labradores que hai oy, y assimismo, os han fabricado à vuestra costa un corto Cuerpo de Iglesia, para que les digan Missa, expliquen la Doctrina Christiana; un Capellan, que assimismo pagan los expressados Vezinos, pero siempre que à estos se les assegure en las tierras, que han empezado à labrar, y se les dèn otras, todo con la firmeza de una Real facultad, para que siempre las tengan à censo, es muy cierto, que assi dichos Vezinos, como Vos, estais determinados à fabricar una capàz Iglesia, siendo todo el costo de ella à vuestras expensas, y de los Vezinos, como con efecto se han empezado à juntar algunos materiales, los quales, como el demàs costo de la Iglesia, nunca podrà subir à mucha cantidad, a causa de tenerlos todos en las inmediaciones de dicho Pueblo, por cuya razon podeis, y pieden à menos costa, que en otros parages, hacer mayor Cuerpo de Iglesia, y mejor, concurriendo Vos con la parte que sea vuestra voluntad, pues podeis muy bien hacerlo, sin tocar à las Haciendas de vuestros Mayorazgos, por tener en dicha Villa un Molino que no es vinculado, diferentes Casas y Viñas, y assimismo, en la de Espinardo, teneis diferentes tahullas, y Casas, todo libre, ademàs 
de las labores que teneis, assi en dichas Villas, como en otros parages, y las muchas gragerias que os pertenecen en la provincia de Extremadura, como de las crias de Ovejas, Bacas, Yeguas, y Cerdos, y otras diferentes Rentas libres que posseeis, por cuya razon, podeis concurrir con aquella parte, ò partes que voluntariamente quisieredes, sin sacar maravedies algunos de los productos de vuestros Mayorazgos, que segun la calidad de las tierras, y por ser mejores las unas que las otras, que unas con otra, y segun el regular computo de un Quinquenio, esando todas laboreadas, y bien cultivadas, podrá producir cada una fanega de tierra en secano, sobre diez reales de vellon, y por cada una fanega en riego sesenta reales de vellon, pero aumentandose los Labradores, produciràn mas: Que lo que oy producen dichos Campos es de cortissima consideracion, pues segun lo que han oìdo decir à todos los Administradores en sus tiempos, no passa el producto de dichas tierras, Jurisdicciones y Pueblos, de diez y seis à veinte mil reales, incluso el Molino, y las labores que Vos teneis de vuestra cuenta, de forma, que es crecidissimo el aumento, que los expressados Mayorazgos recibiràn, luego que todas los expressadas tierras se dèn à censo emphiteutico, y Renta perpetua, à los Labradores que han empezado à venir, y que estàn esperando este nuevo establecimiento para empezar sus labores; pero con lo que mas excesivamente subiràn los productos de dichas Rentas, es con las nuevas fuentes de agua, que Vos habeis sacado à vuestra costa, y puesto en riego, pues con èl se beneficiaràn mas de tres mil tahullas desde aora, y mas adelante, con otras fuentes que actualmente estáis sacando, de manera, que lo menos que podrà producir cada tahulla en riego, serà quince reales de vellon, ò mas, por haversele aumentado mucho las aguas del riego; por lo que serìa conveniente concederos la expressada facultad. Y que habiendose notificado la citada mi Cedula, à Don Francisco de Vera y Quiñones, vuestro hijo Primogenito, è inmediato subcesor al dicho Mayorazgo, no lo contradixo: Visto todo en el referido mi Consejo de la Camara, juntamente con lo que en su virtud dixo mi Fiscal de ella, por Decreto de doze de Mayo proximo passado, se os concediò como lo pedis; y conformandome con ello lo he tenido por bien; y por la presente de mi proprio motu, cierta ciencia, y Poderìo Real absoluto, de que en esta parte quiero usar, y uso como Rey, y Señor natural, no reconociente superior en lo temporal, doy, y concedo licencia, y facultad à Vos, el dicho Don Diego Alonso de Entenza Faxardo y Vera, Marquès de Espinardo, para que podais vender à censo perpetuo emphiteutico, todas las tierras de los terminos de las Villas de Ontur, Albatana, y Mojon blanco, assi de riego, como de secano, y las aguas de ellos que actualmente hai, y de nuevo, se descubran pertenecientes al citado Mayorazgo, de que sois posseedor, y fundaron los dichos Don Alonso de Entenza Pacheco, y Doña Aldonza Cascales, à la persona, personas, o Comunidades, con quienes la teneis tratado en la forma, con las condiciones que arriba quedan expressadas, y otorga sobre ello las cartas de venta à censo, y otras cualquier Escrituras, que para firmeza, y validacion de ello fueren necessarias, las quales, Yo por la presente confirmo, y apruebo, è interpongo à todas, y cada una de ellas mi Authoridad Real, y quiero, y mando, que valgan, y sean tan firmes, bastantes, y valederas, en quanto fueren conformes, y no excedieren de lo contenido en esta mi Carta, sin embargo del dicho vuestro Mayorazgo, y qualquier clausulas, y condiciones de él, Leyes, fueros, y Derechos, usos, y costumbres, expeciales, y generales, hechos en Cortes, ò fuera de ellas, que en contrario de esto sean, o ser puedan, que para en quanto à ello toca, y por esta vez dispenso, y lo abrogo, y derogo, caso, y anulo, y doy por ninguno, y de ningun valor, quedando en su fuerza, y vigor, para en lo demás adelante. Y para este efecto, y no otro alguno, aparto, y divido del dicho Mayorazgo, y de sus clausulas, y condiciones las mencionadas tierras, y las hago libres, no obligadas, ni sugetas à vinculo, ni restitucion alguna, con tanto que sean propias del dicho vuestro Mayorazgo, porque mi intencion, y voluntad, no es de 
perjudicar en ello à mi Corona Real, ni otro Tercero alguno, que no sea de los llamados à èl, y con que los dichos censos perpetuos, y lo demàs que se os diere por las citadas tierras, queden respectivamente unidos, subrogados, è incorporados en el expressado vuestro Mayorazgo, à que como va referido pertenecen, para que lo esten perpetuamente con las mismas clausulas, vinculos, gravamenes, y condiciones, con que estaban las dichas tierras, y lo estàn los demàs sus biens, que yo desde aora los he por unidos, subrogados, è incorporados en el dicho vuestro Mayorazgo, todo lo cual se ha de notar, y prevenir en la Escriptura Original de su Fundacion, y en las demàs partes que convenga, para que en todo tiempo confie à sus posseedores. Y mando al Escribano, ò Escribanos, ante quien se hicieren, y otorgare las dichas Escripturas, que incorporen en ellas el traslado de esta mi Facultad, para que en todo tiempo se guarde, y cumpla, y no se exceda de lo en ella contenido, y contra seu tenor, y forma, no se vaya, ni passe en manera alguna. Y à los del mi Consejo, Presidentes, y Oidores de mis Audiencias, y Chancillerìas, y otros qualesquier mis Juezes, y Justicias de estos mis Reynos, y Señorìos, que la guarden, y cumplan, y hagan guardar, y cumplir, como en ella se expressa. Dada en Aranjuèz à quince de Junio de mil setecientos cincuenta y uno. YO EL REY.- El Obispo de Siguenza.- El Marquès de Lara.- El Marquès de los Llanos.- Yo Don Agustin de Montiano y Luyando. Secretario del Rey nuestro Señor, le hice escribir por su mandato.

\section{A. H. P. Albacete, Sección Audiencia}

Civil, caja 155, legajo I.

\section{DOCUMENTO II}

Escritura de compromiso de venta de los censos enfitéuticos y derechos que D. Eduardo Wall y Vera de Aragón poseía en los términos municipales de Ontur y Albatana. Año 1879.

En la Villa de Hellín a siete de Junio de mil ochocientos setenta y nueve; ante mí D. Miguel Navarro Martínez, Notario de este Distrito, vecino y residente en esta dicha Villa y de los testigos que se expresarán Comparecen:

De una parte D. Antonio Navarro y Corrochano, de cincuenta y un años de edad, de estado casado, administrador de loterías, vecino de la ciudad de Murcia, según su cédula personal número ciento sesenta y nueve de orden, expedida en dicha ciudad en ocho de enero último que en este acto me exhibe y, le devuelvo, en concepto de mandatario del Sr. D. Eduardo Wall y Vera, según aparece la copia de poder que de la misma manera me exhibe para acreditar su personalidad y que lo inserte en esta Escritura; y cuyo contenido literal del mismo a la letra dice así:

Copia de poder: En la Villa de Madrid a catorce de Febrero de mil ochocientos setenta y ocho, ante mi D. Francisco Morcillo y León, Notario del Ilustre Colegio de este Territorio y vecino de la misma comparece. El señor don Eduardo Wall y Vera, mayor de edad, soltero, propietario y vecino de esta Corte, según su cédula personal que exhibe y recoje del Distrito municipal de Buena Vista, fecha nueve de octubre último, número ochocientos siete. Y hallandose a mi juicio con la capacidad legal necesaria que manifiesta no estarle limitada para formalizar esta Escritura de mandato, declara: Que confiere el poder general tan 
amplio y bastante como, en derecho se requiere a don Antonio Navarro y Corrochano, mayor de edad, casado, administrador principal de loterías y vecino de la ciudad de Murcia para que en nombre y representación del otorgante practique lo siguiente. Primero: administre, rija y gobierne los bienes de cualquier clase que al otorgante pertenezcan y puedan pertenecer en lo sucesivo en las provincias de Murcia y Albacete y en cualesquiera otras de la Península, atienda a su conservación, reparo y cultivo, en lo que invierta las cantidades necesarias; recaude sus rentas y productos; satisfaga sus cargas y obligaciones, y practique las demás gestiones propias de un celoso y entendido administrador eligiendo y nombrando caso necesario bajo su responsabilidad y dirección, administradores - subalternos guardas de campo y demás dependencias que fueren necesarios. Segundo: constituya arrendamientos e inquilinatos por el tiempo, precio y condiciones que estime convenientes, autorice sub-arriendos, estipule el pago de las rentas en dinero o en frutos según fuere más ventajoso; celebre al efecto subastas cuando lo crea oportuno, entendiéndose especialmente autorizado para que aquellos contratos de arriendo que por sus estipulaciones estuvieren comprendidos dentro de las prescripciones de la Ley Hipotecaria se solemnicen de nuevo de modo que puedan ser debidamente inscritos en los Registros de la Propiedad correspondientes. Tercero: Desahucie inquilinos, colonos y arrendamientos utilizando al efecto los medios y trámites establecidos por las Leyes de procedimientos con embargo de bienes e indemnización de perjuicios en su caso. Cuarto: Reclame y cobre cuantas cantidades de dinero, frutos, géneros y efectos públicos correspondan al otorgante cualesquiera que sea su origen y procedencia, practicando al efecto las gestiones necesarias y dando de lo que cobrare los recibos, cartas de pago, cancelaciones de hipotecas y demás resguardos competentes. Quinto: Satisfaga los censos, cargos, tributos, y obligaciones á que estuvieren afectos los bienes del otorgante, salarios de dependientes y demás débitos, recojiendo los resguardos y recibos que correspondan. Sexto: Tome cuentas a todos los que por cualquier concepto debieran rendirlas al otorgante, las examine, exponga los reparos que contengan, nombre caso necesario Contadores en unión de los elegidos por la otra parte y tercero en discordia y aclarados los agravios o no teniédolos, las apruebe y se incaute o satisfaga el alcance que en favor o en contra resulte y otorgue los finiquitos y demás documentos procedentes. Séptimo: Transija los créditos y derechos y acciones pertenecientes al otorgante ya en litigio ó fuera de él, estipulando las bases y condiciones de la avenencia, haga condenaciones de créditos, conceda plazos y esperas, someta su decisión al juicio de árbitros o de amigables componedores que nombrará por su parte otorgándose al efecto las escrituras de transacción y de compromiso correspondientes. Octavo: Asista a juntas de cualquiera clase así como á las de distribución y aumento de aguas de riego, nombramiento de acequieros y juntas, aprobación de reglamentos u ordenanzas, deslindes de términos y heredades, evaluación para pago de contribuciones, y demás en que tenga interés el otorgante, emitiendo su parecer y voto, se conforme con lo que la mayoría resuelva o proteste contra sus acuerdos proponiendo los recursos que procedan, ante las autoridades competentes. Noveno: Admita en pago de deudas. Fincas y toda clase de bienes, muebles y semovientes por su valor en tasación o por el que convenga, con las condiciones que conceptúe aceptables. Décimo: Conceda ó tome terrenos á censo estableciendo los pactos y condiciones propios de su naturaleza, perciba o pague el canon, los redima en la forma en que se conviniere y formalice los documentos que al efecto procedan. Undécimo: Acepte sólo con beneficio de inventario toda clase de bienes que correspondan al otorgante por sucesión testada o intestada, intervenga en su formación, nombre depositarios, peritos y contadores, tome posesión y se incaute de los bienes adjudicados y obtenga los testimonios y títulos de propiedad correspondientes. 
Duodécimo: Compre y venda toda clase de frutos y bienes, muebles e inmuebles de la propiedad del otorgante, en subasta o fuera de ella, fijando los precios, pactos y condiciones que estime convenientes, incluso el de retrovento, reciba ó pague los precios de presente confesados o aplazados, en este caso garantizados con las convenientes hipotecas, formalice á su tiempo las oportunas escrituras de retroventa que haga cuanto sea necesario hasta ultimar estos asuntos. Décimo-tercero: Permute asímismo cualesquiera clase de bienes, satisfacción o cobrando las diferencias y formalizando los documentos correspondientes. Décimo-cuarto: Dé y tome a préstamo cantidades en dinero efectivo y de cosas fungibles con el interés, tiempo y condiciones que la parezcan ventajosas, cobrando y satisfaciendo el capital y los réditos á sus respectivos vencimientos, cuyo pago podrá garantir ó exigir que se garantice con hipoteca, fianza o en cualquier otra forma. Décimo-quinto: Proceda al deslinde y amojonamiento de términos y cualesquiera predios del otorgante, haciendo las peticiones que procedan á las autoridades administrativas ó judiciales para que nombrándose peritos por su parte y la de los dueños colindantes, se exige la exacta extensión de las propiedades y servidumbre de cada una. Décimo-sexto: Conceda por ajuste alzado ó por via de arrendamiento el derecho de pacer los ganados, aprovecharse de la caza, leñas, madereas y demás que produzcan los montes y terrenos estipulando los pactos y condiciones convenientes. Décimo-séptimo: Conceda licencias á los dueños útiles para vender bienes acentuados, previo el pago del Luismo y pensiones vencidas aprobando los contratos. Décimo-octavo: Pida anotación preventiva de bienes inmuebles y derechos reales en los Registros de la propiedad cualquiera que sea el asunto o negocio en que convenga hacerlo, convirtiéndola en su caso en inscripciones definitivas con arreglo á la Ley y cancelando unas y otras cuando así corresponda. Décimo-noveno: Promueva gestiones, expedientes posesiorios y de propiedad de inmuebles, obtenga títulos, documentos é inscripciones, y practique judicial y extrajudicialmente cuanto sea necesario hasta dejar perfectamente arreglada la titulación de las fincas. Vigésimo: Formalice por medio de instrumentos públicos con todos los requisitos y solemnidades legales los contratos que celebre por virtud del presente poder. Vigésimo-primero: Celebre en los Juzgados municipales actos de conciliación y juicios verbales con avenencia o sin ella, lo someta en árbitros, pida la ejecución de lo convenido y obtenga certificados; y en cuanto a los segundos aduzca pruebas, oiga sentencias, las consienta, ó apele y reclame su nulidad siguiendo estos recursos hasta su terminación. Vigésimo-segundo: Finalmente represente y defienda el otorgante como actor ó como demandado y en todas instancias, juzgados y Tribunales ordinarios y especiales, en todos los pleitos, causas y negocios promovidos y que se promovieren, incluso los interdictos, desahucios, juicios universales y los asuntos de jurisdicción voluntaria, á cuyo fin presente escritos, documentos, alegatos y peticiones, formule y conteste artículos, haga recusaciones y juramentos, asista á juntas inventarios y tasaciones, conceda quintas y esperas, pida embargos preventivos, aceptando la responsabilidad de embargos, ejecuciones, prisiones y solturas, venta y remate de bienes, se oponga á cuanto de contrario se intentare, practique pruebas, tache las contrarias, oiga notificaciones e interponga los recursos de apelación, súplica, quejas, nulidad, casación y demás ordinarios y extraordinarios que procedan, se separe y desista de ello, o la siga por sus trámites legales, hasta obtener ejecutoria y su cumplimiento. Tales son las facultades con las de sustituir este poder en todo ó en parte, rebocar los sustitutos, y nombrar y pasar por cuanto en su virtud se hiciere. Así lo otorga el compareciente y lo firma con los testigos instrumentales sin impedimento legal don Paulino Abad y don Miguel de San José, vecinos de esta Corte y habiendo leído á todos por su elección esta Escritura íntegra, después de advertidos que tienen el derecho de leerla por si, presta el primero al acto su conformidad y libre consentimiento. $Y$ yo el Notario de 
conocer al otorgante y de todo lo contenido en este Instrumento público, doy fé. Eduardo Wall y Vera. Paulino Abad. Miguel de San José. Signado Francisco Morcillo y León. (...)

Y de la otra parte comparecen don Pascual Abellán Sánchez, de estado casado, propietario, de cincuenta y cinco años de edad, vecino de la ciudad de Murcia, según su cédula personal número cuatro de órden, expedida en treinta de noviembre último; don Antonio Moreno y Abellán, mayor, de setenta años de edad, estado viudo, propietario, vecino de Ontur, según su cédula número ciento diez de orden expedida por la Alcaldía de dicha Villa en veintiseis de diciembre último; don José Ventura Cantos y Abellán, de cincuenta años de edad, también propietario, de estado casado, de la misma vecindad (...); don Pascual Cantos Martínez, de igual estado, también propietario, de sesenta años, de la misma vecindad (...); don Antonio Abellán Moreno, de igual estado, de treinta y siete años de edad, de igual vecindad también, propietario (...); don Benito Moreno Inza, del mismo estado, de cincuenta y tres años de edad, también propietario, vecino de la villa y corte de Madrid (...); don Leoncio Cantos y Diaz, de estado soltero, de cincuenta años de edad, vecino de Ontur (...); doña Agustina Abellán y Moreno, de estado viuda, propietaria, de sesenta y ocho años de edad (...); doña Josefa Abellán Moreno, igual estado, vecindad y edad, propietaria (...); don Juan Lorente y Escudero, de cuarenta y nueve años de edad, estado casado, también propietario, vecino de Albatana (...); don Victoriano Hernández Córcoles, de igual estado y vecindad, también propietario, de cincuenta y dos años de edad (...); don Fernando Barba y García, del mismo estado y vecindad, también propietario, de cincuenta y seis años de edad (...); don Bartolomé Martínez Giménez, del mismo estado y vecindad, también propietario, de sesenta y tres años de edad (...); don Juan Benito Soria y Ferríz, del mismo estado, también propietario, de cuarenta y cuatro años de edad, vecino de esta villa (...); don Nicolás Lorente y Pérez de los Cobos, de igual estado de setenta y cuatro años de edad, también propietario, vecino de Ontur (...); y don Salvador Abellán Sánchez, del mismo estado y vecindad, también propietario, de cincuenta y ocho años de edad (...); de cuyos conocimientos y demás circunstancias, yo el Notario doy fé.

Y asegurando hallarse todos en el libre uso de sus derechos civiles, con la administración de sus bienes y con capacidad legal para contratar y para esta comparecencia el don Antonio Navarro como mandatario de don Eduardo Wall y Vera y los demás comparecientes en representación propia según dejan acreditado uno y otros y por consiguiente en aptitud legal para otorgar esta Escritura de compromiso de venta de fincas y derechos, expusieron los hechos siguientes:

Primero. Que como a la fundación del Marquesado titulado de Espinardo correspondió en dominio pleno de las villas de Ontur y Albatana que por sus poseedores fueron dadas ambas en su mayor parte tanto los terrenos como edificios y agua a censo perpetuo enfitéutico con carga de Luismo o Fádiga; en cuya posesión han venido sucediéndose los poseedores de dicho mayorazgo hasta recaer en el actual don Eduardo Wall y Vera vecino de Madrid.

Tomo 381. Libro 18 de Ontur. Folio 56. Finca núm. 998. Inscripciones $1^{a}$ y $2^{a}$.

Tomo 366. Libro 26 de Albatana. Folio 223. Finca núm. 1.507. Inscripciones $1^{a}$ y $2^{a}$.

Segundo. Que dicha dación a censo se hizo bajo la obligación de pagar los colonos o enfitéutas de las fincas que les repartieron, el canon de frutos que según la Escritura de dación a cada clase de éstas le consignaron, la de no poder enagenar sin previo permiso y autorización del Señor Marqués ninguna de dichas fincas abonándole a éste en primer 
lugar la décima parte de su valor y, desde hace pocos años, según sentencia ejecutoria el dos por ciento con la facultad de ser preferido el Señor del dominio directo a quedarse con la finca por el tanto que se tratase de enagenar y con las prohibiciones que en la mencionada Escritura de dación a censo se refieren.

Tercero. Que los lindes generales de las relatadas villas de Ontur y Albatana son, por Saliente el término de la villa de Jumilla y el de esta población, por Poniente el término de la inmediata villa de Tobarra y por el Norte los términos de Tobarra y Fuente-Alamo; sin que dentro de dicho perímetro se halle propiedad alguna particular, o sea que no pertenezcan ya en dominio directo o ya en dominio pleno al señor don Eduardo Wall y Vera, tanto de sus terrenos, como de montes, aguas y edificios que encierra dentro de aquél; adquiridas unas por la sucesión a dicho mayorazgo y otras por contrato de compra-venta.

Cuarto. Que además por cesión que hizo al don Eduardo Wall y Vera un Administrador que tuvo en la villa de Albatana hace años llamado Ródenas y cuyo nombre no recuerdan en este acto los comparecientes, por créditos o alcances que resultaron de sus cuentas adquirió de dicho señor como unas setenta y ocho fanegas o sean cincuenta y una hectáreas, setenta áreas y treinta y ocho centiáreas de tierra secano en el término municipal de esta villa, lindantes por Saliente de Juan Antonio Molina, Mediodía camino de Tobarra a Jumilla, Poniente herederos de don Francisco Lorente y Norte término de Albatana, cuyos terrenos dió también a dicho censo enfitéutico como lo estaban los de las dos villas de Ontur y Albatana a varios vecinos de dicho Albatana y Jumilla.

Quinto. Que del todo que comprenden los términos de Ontur y Albatana, como ya se ha dicho pertenece en pleno dominio al don Eduardo Wall y Vera varias fincas unas porque sus antecesores se las reservaron al hacer la dación a censo y otras por compras hechas por dicho señor; cuyas fincas son las siguientes.

Una casa en la villa de Ontur y su plaza de la Constitución marcada con el número primero que linda por la derecha entrando Ana López, izquierda la Iglesia y espalda don Francisco Moreno.

Tomo 381. Libro 18 de Ontur. Folio 67. Finca número 999. Inscripción $1^{a}$.

Otra casa en la misma villa habilitada para casa consistorial y cárcel, en la expresada plaza sin número y linda por la derecha entrando plazuela o calle del Horno, Izquierda y espalda Adriano Tomás.

Tomo 381. Libro de Ontur. Folio 73. Finca número 1000. Inscripción $1^{a}$.

Otra casa horno en la misma villa y su calle del Horno, marcada con el número nueve y linda por la derecha entrando plazuela de esta calle izquierda don Antonio Moreno y espalda el mismo.

Tomo 381. Libro 18 de Ontur. Folio 79. Finca número 1001. Inscripción $1^{a}$.

Otra casa llamada Carnicería en la expresada villa y plaza de dicha calle del Horno, marcada con el número ciento, linda por la derecha entrando calle del Horno, izquierda calle de la Tercia y espalda Antonio García.

Tomo 381. Libro 18 de Ontur. Folio 85. Finca número 1002. Inscripción $1^{a}$.

Una almazara o molino de aceite, situada en la expresada villa y callejón de la Tejera sin número, linda por la derecha entrando con callejón de la Tercia, izquierda don Eloy Alcántara y espalda egidos de la balsa de la Tejera.

Tomo 381. Libro 18 de Ontur. Folio 91. Finca número 1003. Inscripción $1^{a}$. 
Una balsa de cocer cáñamo, situada en dicha villa y sitio del camino de Albacete con el que linda por Saliente, Mediodía camino Servidumbre. Poniente y Norte acequia madre.

Tomo 381. Libro 18 de Ontur. Folio 91. Finca número 1004. Inscripción $1^{a}$.

Veinte tahullas cinco octavas y diez y seis brazas o sean dos hectáreas treinta áreas y cuatro centiáreas tierra riego blanca en la huerta de arriba de dicha villa de Ontur y partido de la Florida, que linda por Saliente acequia madre, Mediodía don Pascual Abellán, Poniente tierra secano del señor don Eduardo Wall y Norte don José Trueba. Cinco fanegas tierra secano en dos pedazos, equivalentes á tres hectáreas, cuarenta y nueve áreas y treinta y cinco centiáreas en dicho término y pago, lindantes por Saliente, acequia madre, Mediodía olivar del mismo don Eduardo, Poniente y Norte doña Concepción Ortuño.

Tomo 381. Libro 18 de Ontur. Folio 109. Finca número 1006. Inscripción $1^{a}$.

Veintiocho tahullas de olivar y viña equivalentes á tres hectáreas, doce áreas y setenta y seis centiáreas en el mismo pago y término, linda Saliente y Norte secano de don Eduardo Wall, Mediodía don Manuel Romero y Poniente herederos de don Joaquín Ortuño.

Tomo 381. Libro 18 de Ontur. Folio 115. Finca número 1007. Inscripción $1^{a}$.

Nueve tahullas de viña con algunos plantones de olivo, ó sea una hectárea y cincuenta y tres centiáreas en el mismo pago y término, linda Saliente herederos de don Joaquín Ortuño. Mediodía los de Bernabé Cantos, Poniente y Norte don Manuel Romero.

Tomo 381. Libro 18 de Ontur. Folio 121. Finca número 1008. Inscripción $1^{a}$.

Un molino harinero con una piedra y diez y siete fanegas tierra riego y secano, equivalentes á once hectáreas, ochenta y siete áreas y setenta y nueve centiáreas, situado todo en el término de la villa de Albatana, linda Saliente, Bartolomé Martínez, Mediodía doña Leocadia Cuadrado y dicho Bartolomé Martínez, Poniente Pedro Balsalobre y Norte el don Juan Lorente.

Tomo 366. Libro 26 de Albatana. Folio 230. Finca número 1508. Inscripción $1^{a}$.

Una casa llamada de la Administración en dicha villa de Albatana y su plaza de la Constitución, sin número y linda por la derecha entrando con Juan Benito Soria, izquierda Pedro Martínez y espalda calle Nueva.

Tomo 366. Libro 26 de Albatana. Folio 234. Finca número 1509. Inscripción $1^{a}$.

Como doce tahullas equivalentes á una hectárea treinta y cuatro áreas y cuatro centiáreas de prado y derecho á una balsa de cocer cáñamo en el partido de la venta término de Albatana que todo linda por Saliente con Antero Lorente, Mediodía acequia madre, Poniente Pedro González y Norte Diego Martínez Gómez.

Tomo 366. Libro 26 de Albatana. Folio 238. Finca número 1510. Inscripción $1^{a}$.

$\mathrm{Y}$ una casa venta situada en el mismo término de Albatana y pago del mismo nombre con dos fanegas de tierra secano contiguas á la misma venta equivalentes á una hectárea, treinta y nueve áreas y setenta y cuatro centiáreas y todo linda por Saliente camino Real, Mediodía acequia madre, Poniente Diego Gómez y Norte Pedro Balsalobre.

Tomo 366. Libro 25 de Albatana. Folio 242. Finca número 1511. Inscripción $1^{a}$.

Sexto. Que según los títulos de pertenencia ya de las fincas de dominio pleno como de las del dominio directo que quedan relatadas como pertenecientes al señor don Eduardo Wall y Vera, aquellas y este no tienen sobre sí carga ni gravamen alguno, en cuyo concepto 
las adquirió por los títulos expresados el referido don Eduardo y en igual concepto las sujeta en su nombre el don Antonio Navarro á este contrato.

Séptimo. Que consultando cada una de las partes comparecientes sus intereses y persuadidas ambas de lo enojosa que es la propiedad en que la una tiene el dominio directo y la otra el útil, como las gravámenes que sobre los de este dominio pesan por cuya razón ni pueden desenvolver los terrenos que con tal carga poseen ni fomentarlos cual exije las cualidades de los mismos terrenos y los adelantos conocidos de la Agricultura, porque el capital que había de emplearse da un pequeño rendimiento que había de venir á redundar en beneficio del señor del dominio directo, el que no tiene necesidad de emplear capital alguno para el aumento de sus rentas, por otro lado es igualmente gravoso á este señor atendidas las cargas reales ó impuestos que tiene que satisfacer, á los sueldos que debe abonar á los Administradores que tiene ó debía tener en dichas villas, y á los demás gravámenes que sobre él pesan por razón de dichas fincas, no desconociendo á la vez ninguna de las partes los disgustos, sinsabores y litigios que á veces trae consigo la división de ambos dominios; les ha hecho en los contratos proponer ser mútuamente medios para evitar unos y otros, habiendo por último concertado el compromiso de compra venta del dominio directo en cuanto á las fincas dadas á censo y del directo y útil ó sea del pleno dominio de las que esclusivamente y en esta forma posee y pertenecen al don Eduardo Wall y Vera.

Y llevando á efecto dicho convenio el don Antonio Navarro y Corrochano en nombre y representación del señor don Eduardo Wall y Vera y en virtud de la facultad que por el poder antes inserto se le confieren, el cual asegura no estarle revocado, suspenso ni limitado y si por el contrario de mandato expreso de su señor poderdante y los señores don Pascual Abellán Sánchez, don Nicolás Lorente Pérez de los Cobos, don Antonio Moreno Abellán mayor, don José Ventura Cantos Abellán, don Pascual Cantos Martínez, don Antonio Abellán Moreno, doña Josefa Abellán Moreno, don Juan Lorente Escudero, don Victoriano Hernández Córcoles, don Fernando Barba García, don Bartolomé Martínez Jiménez, don Salvador Abellán Sánchez y don Juan Benito Soria y Ferriz, por si.

Otorgan. Que celebran esta Escritura de compromiso de compra-venta de las fincas propias en ambos dominios que pertenecen al don Eduardo Wall y del dominio directo que igualmente corresponde á dicho señor sobre las demás fincas de las villas de Ontur y Albatana y de la que se ha descrito en el término municipal de esta villa, bajo las bases, cláusulas y condiciones siguientes:

Primera: Que promete el don Antonio Navarro y Corrochano en nombre de su principal don Eduardo Wall y Vera ceder y traspasar en venta las fincas que su poderdante posee en pleno dominio como los derechos que tiene ó posee por dominio directo tanto sobre las demás fincas rústicas, urbanas, montes, remanentes de aguas ó fuentes que dentro del perímetro descrito que comprenden los términos municipales de las villas de Ontur y Albatana y la finca enclavada también y descrita en el término municipal de esta población a los señores comparecientes don Pascual Abellán Sánchez, don Nicolás Lorente y Pérez de los Cobos, don Antonio Moreno Abellán mayor, don José Ventura Cantos Abellán, don Pascual Cantos Martínez, don Antonio Abellán Moreno, don Benito Moreno Inza, don Juan Lorente Escudero, don Victoriano Hernández Córcoles, don Fernando Barba García, don Bartolomé Martínez Jiménez, don Salvador Abellán Sánchez, don Juan Benito Soria y Ferriz en precio y valor de trescientas mil pesetas ó sean de un millón doscientos mil reales que dichos señores se obligan a entregar al don Eduardo Wall y Vera ó á quien legitimamente le represente en doce plazos iguales de veinte y cinco mil pesetas cada uno, que el primero lo tiene ya recibido desde el día primero de abril último; y cada 
uno de los once plazos restantes los ha de recibir en igual día primero de abril de los años sucesivos o sea mil ochocientos ochenta y uno, ochenta y dos, ochenta y tres, ochenta y cuatro, ochenta y cinco, ochenta y seis, ochenta y siete, ochenta y ocho, ochenta y nueve y noventa.

Segunda. Que como consecuencia de este contrato los señores adquirentes han entregado al compareciente don Antonio Navarro y Corrochano en el citado día primero de Abril último las veinte y cinco mil pesetas, importe del primer plazo en monedas de oro y plata que contadas las importaron, de cuya entrega en nombre y representación del Sr. don Eduardo Wall y Vera otorga á favor de aquellos carta de pago y recibo en forma.

Tercera. En este acto yo el Notario declaro que confesada como lo está la entrega del primer plazo, ó sea las veinte y cinco mil pesetas referidas, no cabe expedición alguna contra la certeza de su confesión aunque después se justificare no ser cierta su entrega en todo o en parte.

Cuarta. La entrega de los once plazos restantes se hará precisamente en iguales monedas de oro ó plata con exclusión de calderilla y de toda clase de papel creado o por crear aun cuando su circulación fuese forzosa, y se verificará dicha entrega en la ciudad de Murcia al señor don Eduardo Wall y Vera, ó á la persona que como legítima representante del mismo deba percibirla.

Quinta. El dominio tanto pleno de unas fincas como el directo de las demás o sea el derecho enfitéutico de canon de frutos, Luismo ó Fádiga no se trasmitirá a los señores don Pascual Abellán Sánchez, don Nicolás Lorente Pérez de los Cobos, don Antonio Moreno Abellán, mayor, don José Ventura Cantos Abellán, don Pascual Cantos Martínez, don Antonio Abellán Moreno, don Benito Moreno Inza, don Leoncio Cantos Díaz, doña Agustina Abellán Moreno, doña Josefa Abellán Moreno, don Juan Lorente Escudero, don Victoriano Hernández Córcoles, don Fernando Barba García, don Bartolomé Martínez Jiménez, don Salvador Abellán Sánchez y don Juan Benito Soria y Férriz, ó á las personas que legítimamente les representen hasta que se haya verificado el total pago de los once plazos restantes o sea de las doscientas setenta y cinco mil pesetas que estos importan y restan por abonar, en cuyo caso el señor Eduardo Wall y Vera ó quien á este legítimamente represente otorgará á favor de aquellos la correspondiente Escritura de venta cuyo otorgamiento se verificará en esta inmediata villa de Ontur en el acto de satisfacer el último plazo; sin embargo las consecuencias de aquel derecho las aprovecharán en los términos que se expresa en la siguiente condición:

Sexta: Desde este día cesará en él don Eduardo Wall y Vera y se transmite á los compradores don Pascual Abellán Sánchez, don Nicolás Lorente Pérez de los Cobos, don Antonio Moreno Abellán mayor, don José Ventura Cantos Abellán, don Pascual Cantos Martínez, don Antonio Abellán Moreno, don Benito Moreno Inza, don Leoncio Cantos Díaz, doña Agustina Abellán Moreno, don Juan Lorente Escudero, don Victoriano Hernández Córcoles, don Fernando Barba García, don Bartolomé Martínez Jiménez, don Salvador Abellán Sánchez y don Juan Benito Soria y Férriz el derecho a percibir los rentos y frutos devengados y no satisfechos hasta primero de Enero del corriente año y los que se devenguen durante el tiempo que ha de transcurrir hasta que se otorgue la Escritura definitiva de venta á dichos compradores o sus representantes cumplen las condiciones que á los mismos se refieren de las contenidas en esta Escritura; pero si dejaren de cumplir alguna de ellas, remanecerá dicho derecho en el señor don Eduardo Wall y Vera, retrotraído á la fecha en que hubiera tenido lugar el pago del último plazo satisfecho. 
Séptima. Los once plazos que restan que abonar se entregarán completos sin que el don Eduardo ni sus sucesores puedan ser obligados á recibir en ningún caso cantidad alguna parcial á cuenta del plazo de deba pagarse la demora de un año en el pago total del plazo o plazos que queden por abonar impondrá á los compradores una pena ó multa de treinta mil pesetas ó sean ciento veinte mil reales que percibirá el señor don Eduardo Wall ó quien lo represente pudiendo exijirla por la vía ejecutiva como cantidad líquida, é igual procedimiento se podrá seguir respecto al plazo ó plazos vencidos y no satisfechos, bastando en uno ú otro caso la presentación de una copia legal de esta Escritura aun cuando no reuna las circunstancias exigidas en el número primero del artículo nuevecientos cuarenta y uno de la Ley de Enjuiciamiento civil. Dicha demora será también causa bastante para la rescisión del contrato si así conviniera al señor don Eduardo Wall, quien en este caso adquirirá el pleno dominio de dichos bienes y derechos y hará suya además de la multa o pena antes expresada, el importe de los plazos que haya percibido.

Octava. Si dicho señor don Eduardo Wall y Vera ó sus representantes, exigieran judicialmente la rescisión del contrato ó por el solo hecho de intentarlo, por otra causa que no sea la falta de cumplimiento de alguna de las condiciones impuestas á los compradores abonará á estos el importe total de los plazos que hubiese percibido, una multa igual á estos impone de treinta mil pesetas ó sean ciento veinte mil reales y á más el importe total á justa tasación perítica de cuantas mejoras por cualquier concepto se hiciere tanto en las fincas que dicho señor posee en pleno dominio como en las que tiene el dominio directo á excepción de las mejoras en las fincas urbanas de las que existen ó puedan edificarse.

Novena. Los señores don Pascual Abellán Sánchez, don Nicolás Lorente Pérez de los Cobos, don Antonio Moreno Abellán mayor, don José Ventura Cantos Abellán, don Pascual Cantos Martínez, don Antonio Abellán Moreno, don Benito Moreno Inza, don Leoncio Cantos Díaz, doña Agustina Abellán Moreno, doña Josefa Abellán Moreno, don Juan Lorente Escudero, don Victoriano Hernández Córcoles, don Fernando Barba García, don Bartolomé Martínez Jiménez, don Salvador Abellán Sánchez, don Juan Benito Soria y Ferriz responderán mancomunadamente sin perjuicio de las obligaciones que entre si ó con terceras personas puedan contraer. La acción ó acciones en su caso por falta de pago podrán dirijirse contra ocho de los compradores ó sea de aquellos ó sus herederos a elección del don Eduardo Wall y los suyos con precisión de los tres de los ocho han de ser vecinos ó terratenientes de la villa de Albatana; entendiéndose que los ocho elegidos asumen su responsabilidad y la de los demás compradores, sin perjuicio de las acciones que contra estos competan á aquellos contra los que haya dirijido la reclamación.

Décima. Corresponde á los compradores satisfacer todas las contravenciones y cargas que de cualquier clase y por cualquier concepto correspondan ó se exijan por razón de los bienes y derechos del don Eduardo Wall y Vera desde primero de abril del año actual.

Undécima. No habrá prorateo de frutos y rentas entre el vendedor y los compradores, quedando en beneficio de estos además de lo ya expresado en la base sexta, las deudas con los enfiteutas ó terratenientes de Ontur y Albatana tengan á favor de don Eduardo Wall y Vera, por razón de dichos bienes y derechos; así como también los utensilios y material de obras que de la pertenencia del mismo haya en las jurisdicciones de ambas villas á virtud de la transmisión del expresado derecho y para que puedan los enfiteutas hacerlo efectivo ha entregado el vendedor á los compradores un estado de las deudas ó sea créditos pendientes para su cobro por los últimos deudores que los hacen. 
Duodécima. Quedan por este contrato ultimados todos los pleitos pendientes entre los compradores ya por sí ó en representación de los censatarios de ambas villas de Ontur y Albatana y el señor don Eduardo Wall y Vera desde hoy para en adelante. Y si alguno de los enfiteutas ó terratenientes siguiera alguno de dichos litigios o tratara de promover alguna otra ú otras cuestiones judiciales por razón de los bienes y derechos ya expresados, será obligación de los compradores sostenerlas á su costa é indemnizar al señor Wall de los gastos y perjuicios que por esta causa se le originen.

Décimo tercia. Teniendo en cuenta que el señor don Eduardo Wall y Vera por esta Escritura se compromete á ceder y traspasar por medio de la venta aplazada á los compradores todas sus fincas y derechos enclavados dentro del perímetro que comprende los términos municipales de Ontur y Albatana y los derechos de dominio directo de la finca existente en el término municipal de esta villa que queda descrita, no podrá ser reconvenido judicial ni extrajudicialmente por falta de cabida ó debida expresión de alguna de las fincas relatadas, diferencia de situación ó linderos ni por ninguna otra causa, debiendo entenderse en todo caso que el compromiso de venta es de todo cuanto le pertenece por dominio pleno ó derecho real y menos pleno de ambas jurisdicciones y en la parte del término de esta villa aun cuando de ello no se hubiese hecho detallada expresión y en tal concepto ha sido admitido este contrato por los señores compradores.

Décimo cuarta. Los gastos que ocasione el otorgamiento de esta Escritura son y se entienden de cuenta de los compradores; pero si alguna de las partes quisiera sacar capia de ella, serán los gastos que ésta origine de cuenta de la parte que lo solicite; en la Escritura definitiva de venta cada parte pagará sus gastos según costumbre.

Décimo quinta. Que como quiera que por este contrato el señor don Eduardo Wall y Vera se desiste por el tiempo del mismo ó sea por el que cumplan este contrato los compradores de percibir y cobrar el canon de frutos y los derechos de Luismo ó Fádiga en los cuales va embebido el de percibir el dos por ciento de las ventas y permutas que puedan hacerse de cualesquiera de las fincas acensuadas, el don Antonio Navarro y Corrochano en nombre de su principal el don Eduardo Wall y Vera transmite desde hoy los mismos derechos que su señor mandatario tenía en favor de don Benito Moreno Inza y don José Ventura Cantos vecinos de Ontur y á don Juan Lorente Escudero y don Fernando Barba García vecinos de Albatana para que juntos ó separadamente cada uno de los dos de las repetidas villas puedan expedir dichas licencias por las fincas que radican en dichos términos y los últimos por la de esta villa hasta tanto que se consolide esta venta ó se rescinda con las penalidades impuestas por cualesquiera de las partes; sin que durante dicho término pueda exijirse por ninguno de los que expidan dichas licencias el dos por ciento á que el señor don Eduardo Wall tenía derecho á percibir ni otra cantidad alguna bajo nigún concepto, como tampoco podrán hacer uso del derecho que dicho señor tenía de adquirir por el tanto las fincas que se trataban de enajenar conforme con la expresada renuncia que tiene hecha.

Décimo sexta. En el caso de que alguno ó algunos de los enfiteutas dejase de satisfacer la parte que por reparto le corresponda para el pago de la compra de dichos derechos al señor don Eduardo Wall ó que por un olvido no contribuyese; el don Antonio Navarro en nombre de su señor mandante faculta á los compradores para que puedan exigir de aquellos todos cuantos derechos podría exijir el señor don Eduardo Wall según la Escritura de dación á censo, pues para este efecto pone á dichos compradores en el mismo lugar y derecho que hasta hoy está su señor poderdante. 
Décimo séptima. El don Antonio Navarro y Corrochano compromete y obliga á su principal don Eduardo Wall y Vera ó á sus sucesores para que en la Escritura de venta se consigne la cláusula de evicción y saneamiento á dicha venta tanto por las fincas que á dicho señor pertenecen en pleno dominio como por el dominio directo que tiene sobre las demás, y en el caso de que pudiera olvidarse insertarla, se entiende desde hoy para entonces puesta en dicha Escritura esta cláusula y obligados á cumplirla el don Eduardo Wall y sus sucesores.

Décimo octava. Ambas partes renuncian en todo caso su fuero de domicilio y se sujetan á los Juzgados municipales y de primera Instancia de la Ciudad de Murcia ó sea á los Tribunales competentes de la misma para toda clase de actos y juicios que sean consecuencia de este contrato.

Décimo novena. Ambas partes contratantes y en la representación que cada una interviene se comprometen á guardar y cumplir estrictamente este contrato y las obligaciones que á cada uno se refiere, declarando no haber habido en él dolo, lesión ni engaño y caso de que lo hubiera como hijo de una inadvertencia renuncian expresamente su reclamación. Así lo otorgan y firman los que saben y por las dos señoras que manifestaron no saber lo harán á sus ruegos los testigos presenciales firmando también por sí, y lo son don Antonio Velasco y Suárez y don Antonio Dayestén Velasco, de esta vecindad, sin excepción para serlo; y enterados todos del derecho que tienen á leer por sí este instrumento lo renunciaron y en su virtud yo el Notario dí lectura de él y enterados todos de su conformidad lo ratificaron. Don Antonio Navarro, Pascual Abellán, Antonio Moreno, José Ventura Cantos, Pascual Cantos, Benito Moreno, Antonio Abellán, Leoncio Cantos, Juan Lorente, Juan Benito Soria, Victoriano Hernández, Fernando Barba, Salvador Abellán, Bartolomé Martínez, Ubeda, Nicolás Lorente. A ruego de doña Agustina Abellán Moreno, Antonio Velasco. A ruego de doña Josefa Abellán Moreno, Antonio Dayestén, Antonio Velasco, Antonio Dayestén. Hay un signo Miguel Navarro Martínez.

Es primera copia de su original que estendido en papel del sello undécimo anotada á su final esta saco y marcado con el número ciento cuarenta y dos obra en mi protocolo corriente de instrumentos públicos del presente año á que me remito. En fé de ello yo el mismo Notario á instancia de los otorgantes $\mathrm{y}$ en fé de ello libro la presente en un pliego de sello primero número nueve mil ciento noventa y nueve y diez y seis del undécimo desde el número tres millones doscientos diez y ocho mil ciento setenta y uno hasta el número tres millones doscientos diez mil y ocho mil ciento cincuenta y seis inclusive contando desde arriba á bajo que signo firmo y sello con el de mi Notaria en Hellín á ocho de junio de mil ochocientos setenta y nueve.

Miguel Navarro Martínez

Archivo municipal de Ontur

\section{DOCUMENTO III}

Memoria presentada por don Adolfo Abellán Lorente a los pueblos de Ontur y Albatana sobre las gestiones practicadas con motivo de la redención de ambas villas.

Hacía tres años que se había cumplido el plazo fijado por los otorgantes de la Escritura de compromiso de venta, de los censos y derechos que don Eduardo Wall y Vera de 
Aragón, (que este señor) poseía en los términos municipales de Ontur y Albatana, y cuya venta debió finalizarse según el citado compromiso en el año 1890, no sin que se gestionara durante dos años consecutivos por parte de la junta llamada de Redención y representante de ambos pueblos el cumplimiento de las cláusulas del contrato; pero nada bastó; surgían dificultades, al parecer insuperables, que imposibilitaban finalizar el convenio que tanta importancia y trascendencia daba á ambas villas; aumentando las dificultades la opinión de los abogados asesores de la citada Junta; los que manifestaban que para llegar al cumplimiento del repetido contrato, había que hacer grandes y dispendiosos gastos por parte de los pueblos, después de los sacrificios y tranquilidad que estos habían prodigado, por sacudir el yugo señorial que los atenazaba; cuando las dificultades se allanaban por parte de los pueblos, surgían por la del señor Wall ó sus apoderados, y lo más lamentable fué la muerte del citado señor Wall en el año 1892 que por esta acreció progresivamente las dificultades en razón de la forma del contrato.

En este estado y en vista de tantas dificultades me encargué por mí y en nombre de la Junta de Redención como vocal de la misma, en gestionar para llevar á un término satisfactorio y de resultado para ambos pueblos el cumplimiento del contrato hasta su inscripción en el Registro de la propiedad del partido.

Empecé mis gestiones en 28 de octubre de 1893 y contra la opinión de los abogados asesores, con un escrito al Registro de la propiedad, (que va por cabeza de la Escritura) con otro análogo á la Dirección General, y debido al cual logré se atendiera á mi petición. Como consecuencia éste pidió la legalización de los pagos efectuados al señor Wall según lo estipulado en la Escritura de compromiso de venta, por medio de una carta de pago otorgada en legal forma por la causa habientes del señor Wall y Vera de Aragón.

Para cumplir con tan justa demanda recurrí al Administrador del difunto señor Wall residente en Murcia, el que me manifestó no estar autorizado para tal asunto; y que á más creía que la Escritura de compromiso de venta era sólo un compromiso personal que no obligaba ni podía obligar á los herederos del señor Wall, y que en la actualidad era la Excma. señora Condesa de Sastago Camarera mayor de S. M. la Reina y sus hijos los Excmos. señores Marqueses de Monistrol y de Aguilar, su negativa me obligó a dirigirme á dichos señores residentes en Madrid á quienes pedí carta de pago en forma como herederos de su tío el señor Wall Marqués del Campillo de Murcia; dichos señores me aplazaron contestación para el día siguiente 30 de noviembre de 1893 y hora de las dos de la tarde; hora en que me presenté acompañado del Diputado á Cortes don Luis García Alonso ante la citada señora Condesa de Sastago y sus abogados asesores don Francisco Silvela y don Juan de Dios de la Raga y Delgado, á quienes repetí mi petición de Carta de pago, haciéndola estensiva para que los señores de Sastago y Monistrol ratificaran la venta efectuada por su señor tío Marqués del Campillo en 7 de junio de 1879, con el caracter de irrevocable y perpétua; contestáronme que á ellos no obligaba el otorgamiento de carta de pago de ninguna especie, por cuanto no habían heredado á su tío más que como usufructuario de la Marquesa del Campillo, y el compromiso de venta entre los pueblos de Ontur y Albatana y su tío don Eduardo, era personal entre ambas partes contratantes, que no se creían obligados á ratificar una venta altamente reconocida como leonina, encontrándose perjudicados como inmediatos sucesores en más de cuatro quintas partes del valor de la venta, como lo justificaría en tiempo oportuno con las cuentas de los Administradores de ambos pueblos y la venta de las fincas que su señor tío tenía en ambas villas en pleno dominio, que así lo creía en derecho, en conciencia y en justicia, y por lo que se negaba á sancionar dicha venta. 
En vista de las dificultades expuestas por los señores de Sastago y Monistrol y á sus indiscutibles derechos, me dirijí a la anciana y noble Condesa de Sastago, manifestándole, que los pueblos de Ontur y Albatana á quienes representaba en esta ocasión, recurrían á ella, no á discutir ni deslindar derechos, sino únicamente á probarle que habían contratado y comprado de buena fé los derechos de su señor tío don Eduardo, que habían sacrificado sus intereses por cumplir fielmente lo estipulado y contratado, que así lo habían creído por espacio de doce años consecutivos y que si los apoderados de su difunto tío habían cotratado con fines ulteriores nunca serían responsables los pueblos á los disturbios, desgracias y pleitos que pudieran renacer de la negativa de sus herederos al cumplimiento del tan sagrado contrato, que comprendiera que los pueblos habían confiado en la nobleza de su difunto tío y que nunca pudieran creer ni esperar, que su último resultado sería una serie de desgracias y un semillero de pleitos, únicamente evitables, con su noble corazón reconociera la justicia de la causa que pedían los pueblos.

Estas palabras inclinaron el ánimo de la noble heredera señora de Sastago, y ordenó que inmediatamente, se otorgase, no solamente la carta de pago pedida sino que también la ratificación de venta e irrevocable y perpétua, como se hizo en el mismo día y hora á favor de los contratantes anteriores y del que suscribe, cediendo para los gastos que se originasen cinco mil pesetas que su difunto tío había dejado de percibir en el último plazo.

Demos un voto de gracia á la anciana y noble dama que supo prever y evitar los graves y trascendentales disgustos que hubiera ocasionado su persistente negativa.

Y nosotros estendiendo nuestra beneficiosa compra en favor de todos los propietarios colonos, que han sacrificado sus intereses para cumplir fiel y noblemente lo estipulado garanticemos sus sacrificios de la forma menos costosa y más satisfactoria para sus intereses.

¡Vivan los pueblos libres!

Ontur 24 de diciembre de 1893

EL ALCALDE

Adolfo Abellán

Archivo Municipal de Ontur 